\title{
Regulation of $\Delta$ FosB Stability by Phosphorylation
}

\author{
Paula G. Ulery, ${ }^{1}$ Gabby Rudenko, ${ }^{2}$ and Eric J. Nestler ${ }^{1}$ \\ ${ }^{1}$ Department of Psychiatry and Center for Basic Neuroscience, and ${ }^{2}$ Department of Biochemistry, The University of Texas Southwestern Medical Center at \\ Dallas, Dallas, Texas 75390-9070
}

The transcription factor $\Delta$ FosB (also referred to as FosB2 or FosB[short form]) is an important mediator of the long-term plasticity induced in brain by chronic exposure to several types of psychoactive stimuli, including drugs of abuse, stress, and electroconvulsive seizures. A distinct feature of $\Delta$ FosB is that, once induced, it persists in brain for relatively long periods of time in the absence of further stimulation. The mechanisms underlying this apparent stability, however, have remained unknown. Here, we demonstrate that $\Delta$ FosB is a relatively stable transcription factor, with a half-life of $\sim 10 \mathrm{~h}$ in cell culture. Furthermore, we show that $\Delta$ FosB is a phosphoprotein in brain and that phosphorylation of a highly conserved serine residue (Ser27) in $\Delta$ FosB protects it from proteasomal degradation. We provide several lines of evidence suggesting that this phosphorylation is mediated by casein kinase 2 . These findings constitute the first evidence that $\Delta$ FosB is phosphorylated and demonstrate that phosphorylation contributes to its stability, which is at the core of its ability to mediate long-lasting adaptations in brain.

Key words: FosB2; FosB; phosphorylation; casein kinase 2; protein stability; proteasomal degradation

\section{Introduction}

The transcription factor $\Delta$ FosB, also designated FosB2 or FosB[short form], is a C terminus-truncated splice variant of the immediate early gene fosb (Dobrazanski et al., 1991; Nakabeppu and Nathans, 1991; Yen et al., 1991). Like full-length FosB, $\Delta$ FosB has a DNA-binding basic domain and a leucine zipper through which it dimerizes with Jun proteins to form activator protein-1 (AP-1) transcription factor complexes, which regulate the expression of many genes (Morgan and Curran, 1995; Rylski and Kaczmarek, 2004). Despite lacking part of the transactivation domain found in the $\mathrm{C}$ terminus of FosB, $\Delta$ FosB functions as both a potent transcriptional activator and repressor in cultured cells and in the brain (Dobrazanski et al., 1991; Nakabeppu and Nathans, 1991; Chen et al., 1997; McClung and Nestler, 2003; Kumar et al., 2005).

$\Delta$ FosB is induced to high levels in a region-specific manner in brain after chronic, but not acute, exposure to a variety of psychoactive stimuli, including stress, certain lesions, antipsychotic and antidepressant drugs, drugs of abuse, and natural rewards (Hope et al., 1994b; Hiroi and Graybiel, 1996; Moratalla et al., 1996; Bing et al., 1997; Mandelzys et al., 1997; Kelz et al., 1999; Werme et al., 2002; Andersson et al., 2003; Colby et al., 2003; Peakman et al., 2003; Perrotti et al., 2004; Zachariou et al., 2006).

Received Nov. 21, 2005; revised Feb. 21, 2006; accepted April 2, 2006.

This work was supported by a National Alliance for Research on Schizophrenia and Depression Young Investigator Award to P.G.U., a National Institute on Drug Abuse (NIDA) National Research Service Award to P.G.U., and grants from the National Institute of Mental Health and NIDA to E.J.N. We thank Dr. James Bibb for his help with the in vitro phosphorylation assays, Dr. Ming-Hu Han for his help with the preparation of brain slices used for metabolic labeling, and Dr. Rachael Neve for her help with the packaging of the recombinant HSVs.

Correspondence should be addressed to Eric J. Nestler, 5323 Harry Hines Boulevard, Dallas, TX 75390-9070. E-mail: eric.nestler@utsouthwestern.edu.

G. Rudenko's present address: Life Sciences Institute and Department of Pharmacology, University of Michigan, 210 Washtenaw Avenue \#3163A, Ann Arbor, MI 48109-2216.

DOI:10.1523/JNEUROSCI.4970-05.2006

Copyright $\odot 2006$ Society for Neuroscience $\quad$ 0270-6474/06/265131-12\$15.00/0
The induction of $\Delta \mathrm{FosB}$ has been related directly to the functional effects of several of these stimuli on the brain. The persistence of $\Delta$ FosB even in the absence of additional stimulation distinguishes it from all other Fos family transcription factors, which are induced rapidly in response to acute stimuli, decay back to basal levels within a few hours, and generally show desensitization after chronic stimulation (Hope et al., 1992; Daunais et al., 1993; Persico et al., 1993; Hiroi and Graybiel, 1996; Perrotti et al., 2004). This makes $\Delta$ FosB an attractive candidate to mediate some of the long-lasting changes in gene expression that underlie the stable neuronal adaptations caused by certain chronic stimuli.

Because the prolonged presence of $\Delta$ FosB occurs in the absence of further induction of its mRNA (Chen et al., 1995), we speculated that, unlike full-length FosB and all other Fos family proteins, which are intrinsically unstable, $\Delta$ FosB may be an unusually stable transcription factor (Hope et al., 1994b; Chen et al., 1997; Nestler et al., 2001; McClung et al., 2004). Moreover, immunoblotting analysis of acute- versus chronic-stimulated brain tissue suggested that $\Delta$ FosB shifts in apparent $M_{\mathrm{r}}$ (molecular mass) from $\sim 33 \mathrm{kDa}$ in the acute condition to $\sim 35-37 \mathrm{kDa}$ during chronic treatment (Hope et al., 1994a; Chen et al., 1995). Because there is no evidence for the existence of additional mRNAs that could encode for these various isoforms, we further speculated that $\Delta$ FosB is posttranslationally modified and that perhaps this contributes to its unusual stability. To date, however, no biochemical analyses of the turnover or posttranslational modifications of $\Delta$ FosB have been reported. The goal of the present study was to determine whether $\Delta$ FosB is a phosphoprotein and whether phosphorylation plays a role in its stability.

\section{Materials and Methods}

Mammalian cell lines and DNA constructs. PC12 cells (Clontech, Mountainview, CA) were cultured in high-glucose DMEM containing L-glutamine (L-Gln) and supplemented with 5\% fetal bovine serum (FBS), 10\% horse serum (both from Invitrogen, Carlsbad, CA), $100 \mathrm{U} / \mathrm{ml}$ 
penicillin, and $100 \mu \mathrm{g} / \mathrm{ml}$ streptomycin (both from Sigma-Aldrich, St. Louis, MO). HeLa cells (American Type Culture Collection, Manassas, VA) were cultured in high-glucose DMEM containing L-Gln and supplemented with $10 \%$ FBS, penicillin, and streptomycin. Both cell lines were maintained at $37^{\circ} \mathrm{C}$ in a humid $5 \% \mathrm{CO}_{2}$ atmosphere.

For the transient transfections with DNA, PC12 or HeLa cells were seeded onto six-well plates (coated with collagen I for PC12 cells) so as to reach $90-100 \%$ confluence the next day and were then transfected using Lipofectamine 2000 (Invitrogen). In some experiments (see Figs. 1-7), $\Delta$ FosB was transiently expressed in PC12 cells via infection with recombinant herpes simplex virus (HSV).

$\triangle$ FosB and FosB cDNAs were obtained from our own pTetopconstructs (Chen et al., 1997), and subcloned into a pcDNA3.1 vector (Invitrogen). These pcDNA3.1- $\Delta$ FosB/FosB constructs were used for expression in mammalian cells and as a template for site-directed mutagenesis. Recombinant HSV- $\Delta$ FosB was prepared as described previously (Neve et al., 1997), and the preparation had a titer of $\sim 1 \times 10^{8} \mathrm{pfu} / \mathrm{ml}$.

Pulse-chase experiments. Approximately $24 \mathrm{~h}$ after infection/transfection, cells (PC12 or HeLa) in six-well plates were washed two to three times with $2 \mathrm{ml}$ of PBS and incubated at $37^{\circ} \mathrm{C}$ for $\sim 1 \mathrm{~h}$ in $2 \mathrm{ml}$ of Cys/Met-free DMEM (Invitrogen) supplemented with 5\% dialyzed FBS (Hyclone, Logan, UT) to deplete intracellular pools of Met and Cys. At the end of this "starvation" period, drugs (if cells were to be treated) were added, and cells were labeled (pulse) with $12-25 \mu \mathrm{Ci}$ of ${ }^{35} \mathrm{~S}$ Protein Labeling Mix (PerkinElmer, Wellesley, MA) for $\sim 1 \mathrm{~h}$ at $37^{\circ} \mathrm{C}$ to label all newly synthesized proteins. The radiolabel was then removed by washing the cells two to three times with $2 \mathrm{ml}$ of PBS, and the ${ }^{35} \mathrm{~S}$-labeled proteins were followed (chase) by replacing the medium with "cold" (nonradioactive) medium supplemented with 5\% FBS and harvesting the cells at various time points. Cell treatments were maintained throughout the chase. All figures of these experiments show similar initial amounts of the various proteins to optimize comparisons of their turnover rates.

Animals and chronic electroconvulsive seizure treatment. Adult Sprague Dawley male rats (200-300 g; Charles River Laboratories, Kingston, RI) were treated once daily with electroconvulsive seizures (ECS) for 7-9 d. ECS was performed as described previously (Hope et al., 1994a) using an Ugo Basile (Comerio VA, Italy) ECS unit with the following settings: frequency, 100 pulses/s; pulse with, $0.5 \mathrm{~ms}$; shock duration, $1.0 \mathrm{~s}$; and current, $75 \mathrm{~mA}$. Sham control animals were treated in parallel by applying the ear-clip electrodes without any electrical current.

${ }^{32} \mathrm{P}$ metabolic labeling. For the labeling of brain slices, rats were decapitated, the brains quickly dissected, and $300 \mu \mathrm{m}$ frontal cortical slices were prepared with a D.S.K. microslicer (Ted Pella, Redding, CA). The slices were incubated inside plastic tubes in $2 \mathrm{ml}$ of phosphate-deficient artificial CSF (ACSF) and maintained at $30^{\circ} \mathrm{C}$ under constant gentle bubbling with an $\mathrm{O}_{2} / \mathrm{CO}_{2}$ mixture (Hemmings et al., 1989). The slices (two slices per tube) were labeled with $1.3 \mathrm{mCi}$ for $8-10 \mathrm{~h}$ in the presence or absence of okadaic acid $(100 \mathrm{ng} / \mathrm{ml})$. At the end of this incubation, the slices were rinsed at least three times with cold ACSF and then homogenized by sonication in $250 \mu \mathrm{l}$ of cold radioimmunoprecipitation assay (RIPA) buffer [PBS, pH 7.4, $150 \mathrm{~mm} \mathrm{NaCl}, 1 \%(\mathrm{v} / \mathrm{v})$ Igepal, $0.5 \%(\mathrm{w} / \mathrm{v})$ sodium deoxycholate, $0.1 \%(\mathrm{w} / \mathrm{v})$ SDS, $1 \mathrm{~mm}$ EDTA] supplemented before use with SDS up to $0.6 \%$, protease inhibitor cocktail for mammalian cells (used at $5 \mu \mathrm{l} / \mathrm{ml}$; Sigma-Aldrich), phosphatase inhibitor cocktails I and II (used at 1:100; Sigma-Aldrich), 1 mM PMSF, and 2\% glycerol. Homogenates were then boiled for $15 \mathrm{~min}$ and cleared by centrifugation at $15,000 \times g$ for $15 \mathrm{~min}$. Protein concentration in the resulting supernatants was assessed using the BCA protein assay (Pierce, Holmdel, NJ).

For the ${ }^{32} \mathrm{P}$ labeling of cultured cells, $\sim 24 \mathrm{~h}$ after infection/transfection, cells were washed two to three times with phosphate-free medium and incubated in this medium for $\sim 1 \mathrm{~h}$. After this starvation period, $0.2-0.3 \mathrm{mCi}$ of ${ }^{32} \mathrm{P}_{-} \mathrm{H}_{3} \mathrm{PO}_{4}$ (PerkinElmer) were added to each well, and cells were labeled for $4-12 \mathrm{~h}$ depending on the kind of experiment (see Figs. 1-7 for specifications). Cells were then washed three times with PBS and lysed on ice for $15 \mathrm{~min}$ with $50 \mu \mathrm{l}$ of supplemented RIPA buffer. Lysates were collected by scraping and were passed 10 times through a 25 ga needle to shear DNA, boiled for $10 \mathrm{~min}$, and centrifuged at 15,000 rpm for $15-30 \mathrm{~min}$ at $4^{\circ} \mathrm{C}$. The cleared lysates (supernatants) were transferred to a new tube and a BCA protein assay (Pierce) was performed. All figures of these experiments show similar amounts of total wild-type (WT) and S27A $\Delta$ FosB proteins to optimize comparisons of their relative phosphorylation levels.

Chemicals and cell culture treatments. Okadaic acid (OA; SigmaAldrich) was dissolved in ethanol and used at a final concentration of 100 $\mathrm{ng} / \mathrm{ml}$. 5,6-Dichloro-1- $\beta$-D-ribofuranosyl-benzimidazole (DRB; $\mathrm{Bi}$ omol, Plymouth Meeting, PA) was dissolved in dimethyl sulfoxide (DMSO; Sigma-Aldrich) and used in cell culture at a final concentration of $50 \mu \mathrm{M}$. Spermine (Sigma-Aldrich) was dissolved in water and used at a final concentration of $200 \mu \mathrm{M}$. Calphostin-C (Biomol) was dissolved in DMSO and used at $0.2 \mu \mathrm{M}$, whereas phorbol 12-myristate 13-acetate (PMA; Promega, Madison, WI) was dissolved in DMSO and used at 0.1 $\mu \mathrm{M}$. myristoylated-autocamtide-2-related inhibitory peptide (m-AIP; Biomol) was dissolved in water and used at a final concentration of 1 and $10 \mu \mathrm{M}$. The broad-spectrum protein kinase inhibitors $\mathrm{H}-7$ and $\mathrm{H}-8$ (Biomol) were dissolved in water and used at a final concentration of 150 and $200 \mu \mathrm{M}$, respectively. MG132 (Calbiochem, San Diego, CA) and epoxomicin (Peptides International, Louisville, KY) were both dissolved in DMSO and used at a final concentration of 12.5 and $7.5 \mu \mathrm{M}$, respectively. In all experiments, DMSO (vehicle) was added to cells as necessary to maintain a constant amount of DMSO across treatments. For ${ }^{32} \mathrm{P}$ labeling experiments, the drugs were added immediately before the label and kept for the remaining of the labeling period. For pulse-chase experiments, drugs were added at the time of Cys/Met "starvation," kept through the labeling period, and then added back into the chase medium. The proteasome inhibitors were spiked every $3-4 \mathrm{~h}$ throughout the chase to compensate for the quick turnover of these peptides.

$\Delta$ FosB immunoprecipitation, immunoblotting, and autoradiography. For immunoprecipitations, lysates were diluted 1:5 with plain RIPA to bring the SDS concentration down to $0.1 \%$ before proceeding with immunoprecipitation (IP). To limit nonspecific binding, the lysates were first cleared by immunoprecipitating with nonimmune $\operatorname{IgG}$ and protein G-Sepharose (Sigma-Aldrich) for at least $4 \mathrm{~h} . \Delta$ FosB was then immunoprecipitated from the cleared lysates using a goat polyclonal antibody that recognizes an internal epitope present in both FosB and $\Delta$ FosB (SC-48G; Santa Cruz Biotechnology, Santa Cruz, CA) at 0.5-1 $\mu$ g IgG per $10 \mu \mathrm{g}$ of lysate protein (50-300 $\mu \mathrm{g}$ of total protein) in a total volume of $0.5 \mathrm{ml}$. IPs were gently mixed at $4^{\circ} \mathrm{C}$ on a rotor for at least $8 \mathrm{~h}$ and then 15 $\mu \mathrm{l}$ of protein G-Sepharose was added and IPs were mixed for at least another $4 \mathrm{~h}$. IPs were pelleted by spinning at $3000 \times g$ for $3-5 \mathrm{~min}$ at $4^{\circ} \mathrm{C}$, washed three times with $0.5 \mathrm{ml}$ of cold plain RIPA and two times with cold PBS containing $0.1 \%$ Tween 20. IPs were then resuspended in $0.5 \mathrm{ml}$ of cold PBS, transferred, pelleted in a new tube, and immunoprecipitated proteins were then eluted by the addition of $15-25 \mu$ l of $2 \times$ reducing Laemmli protein sample buffer. This IP protocol resulted in the specific and effective precipitation of virtually all of the $\Delta \mathrm{FosB}$ in the lysate. The immunoprecipitated proteins were subjected to SDS-PAGE by loading the whole IP on a $12.5 \%$ Tris- $\mathrm{HCl}$ Criterion gel (Bio-Rad, Hercules, CA), and then transferred onto PVDF or nitrocellulose. After transfer, the membrane was air-dried and ${ }^{32} \mathrm{P}$ - and ${ }^{35} \mathrm{~S}$-radiolabeled protein bands were observed by autoradiography using Kodak (Rochester, NY) autoradiographic film, as well as by phosphorimaging using a Storm (Amersham Biosciences, Piscataway, NJ) PhosphorImager. Total (unphosphorylated and phosphorylated) $\Delta$ FosB in cell lysates or brain homogenates was detected by immunoblotting of either the immunoprecipitated protein (using the same membrane used to detect the ${ }^{32} \mathrm{P}$ labeled protein), or of equal amounts of lysate/homogenate protein subjected to SDS-PAGE and transferred onto PVDF or nitrocellulose. The membrane was first blocked by incubating it with $1 \%(\mathrm{w} / \mathrm{v})$ nonfat dry milk (Bio-Rad) in PBS supplemented with $0.1 \%$ (v/v) Tween 20 (Sigma) for $1 \mathrm{~h}$ at $25^{\circ} \mathrm{C}$. The membrane was then immunoblotted overnight at $4^{\circ} \mathrm{C}$ with our own rabbit anti-FosB polyclonal antibody generated against amino acids $1-16$ of FosB $/ \Delta$ FosB (used at $1: 10,000$ ). After primary incubation, membranes were washed four times for 5 min with blocking buffer, and then incubated at $25^{\circ} \mathrm{C}$ for $\sim 1 \mathrm{~h}$ with a goat anti-rabbit IgG conjugated to horseradish peroxidase (used at 1:5000 in blocking buffer, from Vector Laboratories, Burlingame, CA). Membranes were then washed three times for 10 min with blocking buffer and one time for 5 min with PBS. Total $\Delta$ FosB protein bands were visualized on Kodak MR 
film by enhanced chemiluminescence (Pierce) and/or by detection of fluorescence using the ECL-Plus reagents (Amersham Biosciences) and the Storm PhosphorImager.

Overexpression and purification of recombinant $\Delta$ Fos $B$ from insect cells. $\Delta$ FosB was overexpressed in Sf9 insect cells as an $\mathrm{N}$ terminus hexa-Histagged protein (N-His(6) $\Delta$ FosB) using the Bac-to-Bac baculovirus expression system (Invitrogen) and following the instructions of the manufacturer. Briefly, the $\Delta$ FosB cDNA (residues 2-237) preceded by the affinity N-terminal tag MGHHHHHHAG was subcloned in the pFASTBacTM1 vector, which was used to generate recombinant baculovirus. Sf9 cells were infected with recombinant virus, and N-His(6) $\Delta$ FosB was purified from cell lysates by several chromatographic steps including affinity chromatography using a nickel column (Qiagen, Valencia, CA), anion exchange using a mono-Q column (Amersham Biosciences), and size exclusion using a gel-filtration column (Amersham Biosciences).

In vitro phosphorylation studies. In vitro phosphorylation reactions for time course and stoichiometry analysis were performed in a volume of 30 $\mu \mathrm{l}$ containing $10 \mu \mathrm{M}$ substrate (N-His(6) $\Delta \mathrm{FosB}$ or a positive control substrate), $250 \mu \mathrm{M} \mathrm{ATP}$, and $1 \mu \mathrm{Ci} / \mu \mathrm{l}\left[\gamma^{-}{ }^{32} \mathrm{P}\right] \mathrm{ATP}$, the buffer supplied by the kinase manufacturer, and one of the following kinases: CK2 (20 ng/ $\mu$ l; Upstate, Charlottesville, VA), CaMKII (10 ng/ $\mu$; Upstate), PKC $(1.6 \mathrm{ng} / \mu \mathrm{l}$; Calbiochem) or p70S6K (2.5 mU/ $\mu \mathrm{l}$; Upstate). Time course reactions were performed by removing $5 \mu \mathrm{l}$ aliquots from the reaction solution at the designated time points and adding an equal volume of $4 \times$ reducing Laemmli protein sample buffer. Michaelis-Menten kinetic parameters for the CK2 reaction were determined under empirically defined linear steady-state conditions. These reactions were performed for $15 \mathrm{~min}$ in a volume of $10 \mu \mathrm{l}$ containing $2 \mathrm{ng} / \mu \mathrm{l}$ enzyme, $250 \mu \mathrm{M}$ ATP, 1 $\mu \mathrm{Ci} / \mu \mathrm{l}\left[\gamma^{-}{ }^{32} \mathrm{P}\right] \mathrm{ATP}$, and $\mathrm{N}-\mathrm{His}(6) \Delta \mathrm{FosB}$ concentrations ranging from 2.5-30 $\mu \mathrm{M}$. All reactions were performed at $30^{\circ} \mathrm{C}$ in a water bath. After SDS-PAGE and staining of the gel with Bio-Safe Coomassie (Bio-Rad), the gel was dried, and ${ }^{32} \mathrm{P}$-phosphate incorporation was assessed by phosphorimaging analysis (see below, Data quantification, calculations, and statistics).

Two-dimensional phosphopeptide map and phosphoamino acid analysis. Both of these analyses were performed as described by Ploegh and Dunn (2000). Briefly, dry gel fragments containing ${ }^{32} \mathrm{P}$-labeled $\Delta$ FosB (either from in vitro reactions or from immunoprecipitates of metabolically labeled cells), were excised, rehydrated, washed, and subjected to tryptic digestion. The supernatant containing the tryptic digestion products was lyophilized and the lyophilate washed several times and resuspended in $10 \mu \mathrm{l}$ of electrophoresis buffer, $\mathrm{pH}$ 1.9. Sample $(3 \mu \mathrm{l})$ was spotted on a cellulose thin-layer chromatography (TLC) plate (Analtech, Newark, $\mathrm{DE}$ ) and separated in one dimension by electrophoresis and the other dimension by ascending TLC. The resulting phosphopeptide maps were visualized by autoradiography and phosphorimaging. For phosphoamino acid analysis, $2 \mu \mathrm{l}$ of the tryptic digests that had been resuspended in electrophoresis buffer were further cleaved by $\mathrm{HCl}$ hydrolysis at $105^{\circ} \mathrm{C}$ for $25 \mathrm{~min}$ in $3 \mathrm{M} \mathrm{HCl}$ under an $\mathrm{N}_{2}$ atmosphere. The reaction was stopped by a sixfold dilution in water, and the mixture was lyophilized. The lyophilate was resuspended in $5 \mu$ l of electrophoresis buffer, $\mathrm{pH}$ 1.9, and spotted on a cellulose TLC plate along with phospho-Ser, -Thr, and -Tyr standards. Electrophoresis was performed over one-half of the length of the TLC plate using electrophoresis buffer, $\mathrm{pH}$ 1.9, and then the plate was transferred into the $\mathrm{pH} 3.5$ buffer, and electrophoresis was performed to completion. The phosphoamino acid standards were visualized by spraying the TLC plate with a $1 \%(\mathrm{v} / \mathrm{v})$ ninhydrin solution in acetone, and the ${ }^{32} \mathrm{P}$-labeled amino acid samples were visualized by both autoradiography and phosphorimaging.

siRNA-induced CK2 $\alpha$ knock-down. We used an RNA interference method to selectively knock-down the levels of CK2 (Di Maira et al., 2005). PC12 cells were seeded onto collagen I-coated six-well plates to reach $\sim 70-80 \%$ confluence the next day, when they were transiently transfected with $20 \mathrm{~nm}$ (final concentration) of either nontargeting siRNA or siRNA directed toward the mRNA of the catalytic $\alpha$ subunit of Rat CK2, using $5 \mu$ l of the transfection agent SilentFectin (Bio-Rad) and following the instructions of the manufacturer. Approximately $24 \mathrm{~h}$ later, cells were transiently transfected with $\Delta$ FosB plasmid, as stated above. Approximately $24 \mathrm{~h}$ later ( $\sim 48 \mathrm{~h}$ after siRNA transfection), cells were subjected to either ${ }^{32} \mathrm{P}$ metabolic labeling or pulse-chase analysis as described above. The following four CK $2 \alpha$ siRNAs were used with similar results: 5'P-CAAACUAUAAUCGUACAUCUU3', 5'P-UCAAUCAUGACAUUAUGCGUU3', 5'P-UAGUCAUAUAAAUCUUCCGUU3', 5'P-AAAUCCCUG ACAUCAUAUUUU3' (Dharmacon, Lafayette, CO). As a negative control, we used Silencer negative control \#3 siRNA from Ambion (Austin, TX). The extent of CK2 knock-down was monitored by immunoblotting using an anti-CK2 polyclonal antibody (cata$\log \#$ 06-873 from Upstate) overnight at a 1:1000 dilution. $\beta$-Tubulin was used as a loading control and detected with a monoclonal antibody (catalog \#05-661 from Upstate) overnight at a 1:20,000 dilution.

Site-directed mutagenesis. Mutation of Ser27 to Ala or to Asp was accomplished using a Quick Change Site-Directed Mutagenesis kit (Stratagene, La Jolla, CA) and following the instructions of the manufacturer. To introduce the Ser 27 mutations in the mouse $\Delta$ FosB protein, the following mutagenesis primers were used. Ser27 to Ala: (reverse primer) 5'GCCGAAGGAGTCCACCGAAGCCAGGTACTGAGACTCGGCGGAGGG3'. Ser27 to Asp (forward primer) 5'CCCTCCGCCGAGTCTCAGTACCTGGATTCGGTGGACTCCTTCGGC3'. The mutated bases are in bold, and the Ser27 codon is italicized.

Bioinformatics. Potential phosphorylation sites and kinases for $\Delta \mathrm{FosB}$ were searched by submitting the mouse protein sequence to specialized databases including ProSite (http://www.expasy.org/prosite/), PredictProtein (Rost et al., 2004), and NetPhosK (Blom et al., 2004).

Data quantification, calculations, and statistics. The amount of protein present in the PVDF or nitrocellulose membrane was quantified using a Storm PhosphorImager and the accompanying ImageQuant software (Amersham Biosciences/Molecular Dynamics). In the cell culture and brain slice phosphorylation studies, the values obtained for the ${ }^{32} \mathrm{P}$ labeled protein were then divided by the values obtained for total $\Delta \mathrm{FosB}$, and expressed as a ratio. In the in vitro phosphorylation studies, the amount of ${ }^{32} \mathrm{P}$-labeled $\Delta$ FosB per mole of $\Delta$ FosB (stoichiometry) was calculated as described previously (Sahin et al., 2004). All measurements were taken within the linearity range of the instrument used. Kinetic parameters were calculated using the Michaelis-Menten model, whereby $V=V_{\text {Max }}[S] /\left([S]+K_{\mathrm{M}}\right)$ and $V_{\text {Max }}=k_{2}\left[E_{\text {Total }}\right]$. The half-life $\left(t_{1 / 2}\right)$ of $\Delta$ FosB and FosB were estimated from the pulse-chase plots (using the nonlinear regression that best fitted the data points) and correspond to the time at which the amount of remaining protein is $50 \%$ of the original. In all figures, the results shown are representative of at least two to three independent experiments. In all graphs, the data shown are averages \pm SEMs $(3 \leq n \leq 16)$. The statistical significance of differences was assessed using an unpaired $t$ test, corrected for multiple comparisons, and the asterisks indicate $p \leq 0.05$.

\section{Results}

\section{$\Delta$ FosB is an unusually stable transcription factor}

Although we have speculated previously that $\Delta$ FosB is a relatively stable transcription factor (Nestler et al., 2001), a direct analysis of the turnover profile of the protein has not to date been performed. To address this question, we conducted pulse-chase experiments using PC12 cells, which have been extensively used as a neuron-like cell line, in which $\Delta$ FosB was transiently expressed via infection with a recombinant herpes simplex virus (HSV$\Delta$ FosB). Newly synthesized proteins were metabolically labeled with ${ }^{35} \mathrm{~S}$-Met/Cys, and the degradation pattern of ${ }^{35}$ S-labeled $\Delta$ FosB $\left({ }^{35} \mathrm{~S}-\Delta\right.$ FosB $)$ was monitored by immunoprecipitating it from cell lysates obtained at various time points after removal of the radiolabeled amino acids. Analysis of the immunoprecipitates by SDS-PAGE and autoradiography revealed that the halflife of $\Delta$ FosB in PC12 cells is $\sim 10 \mathrm{~h}$ (Fig. 1). These findings show that the half-life of $\Delta$ FosB is higher than that of most inducible transcription factors (see Discussion), including full-length FosB, whose half-life in cell culture has been reported to be $\sim 90$ min (Dobrazanski et al., 1991; Carle et al. 2004). In addition, it is worth noting that the degradation of $\Delta$ FosB does not fit a firstdegree exponential decay curve, but rather it is biphasic, starting 


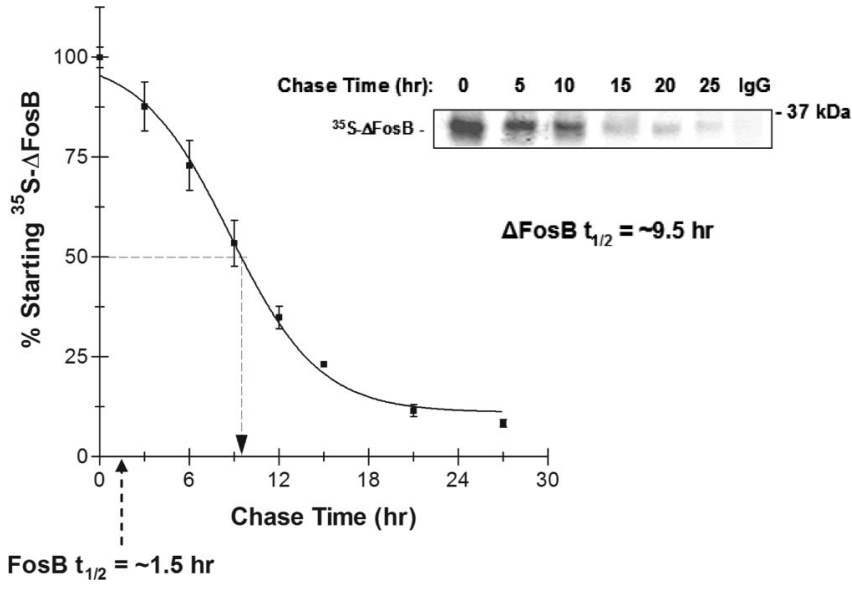

Figure 1. $\Delta \mathrm{FosB}$ is an unusually stable transcription factor. The half-life of $\Delta \mathrm{FosB}$ is $\sim 10 \mathrm{~h}$ in cell culture. $\Delta$ FosB was expressed in $\mathrm{PC} 12$ cells by either infection with $H S V-\Delta F$ osB or transient transfection with $\Delta$ FosB-containing plasmid, and cells were subjected to pulse-chase experiments as described in Materials and Methods. Equivalent results were obtained regardless of the method used to overexpress $\Delta$ FosB. The figure shows the time course (and representative autoradiogram) of $\Delta F$ OSB degradation. The data plotted are the average \pm SEM of at least 15 individual data points obtained from at least five independent experiments. For comparison, the reported half-life of full-length FosB is indicated.

off with a slower degradation rate. This suggests the existence of more than one $\Delta$ FosB species and/or more than one degradation pathway.

\section{$\Delta$ FosB is a phosphoprotein in brain}

We have hypothesized that posttranslational modification of $\Delta$ FosB may contribute to its apparent stability. Because phosphorylation has been shown to modulate the activity of transcription factors in many ways, including their stability (for review, see Desterro et al., 2000; Whitmarsh and Davis, 2000), we investigated whether $\Delta$ FosB is a phosphoprotein. To this end, $\Delta$ FosB expression was induced in rat brain using chronic ECS, a treatment known to induce high levels of $\Delta$ FosB, particularly in frontal cortex (Hope et al., 1994a). One day after the last ECS treatment, when $\Delta$ FosB levels remain high, thin frontal cortical slices were prepared and metabolically labeled with ${ }^{32} \mathrm{P}$ orthophosphate. A parallel set of slices was not radiolabeled, and these were used to detect total $\Delta$ FosB levels. After immunoprecipitation with a specific anti-FosB $/ \Delta$ FosB antibody and separation of the immunoprecipitated proteins by SDS-PAGE, phosphorylated ${ }^{32} \mathrm{P}$-labeled $\Delta$ FosB was detected by autoradiography, whereas total $\Delta$ FosB was detected by immunoblotting. This analysis revealed that $\Delta$ FosB is phosphorylated in brain, as evidenced by a specific ${ }^{32} \mathrm{P}$-labeled band of $\sim 35 \mathrm{kDa}$ present in the chronically treated brain samples, but is virtually undetectable in the sham-treated controls (Fig. 2A). This is consistent with the fact that, in the absence of chronic stimulation, basal levels of $\Delta \mathrm{Fos} B$ are very low. The specificity of the immunoprecipitation reaction is illustrated by the lack of signal in the nonimmune IgG precipitate.

As a first step toward elucidating which kinase(s) and site(s) are involved in $\Delta$ FosB phosphorylation, we subjected its amino acid sequence to several bioinformatic analyses. This revealed that, although $\Delta$ FosB contains no Tyr phosphorylation candidate sites, it does contain several Ser/Thr kinase consensus sites, including three CaMKII sites, three CK2 sites, and two PKC sites with very high phosphorylation prediction scores (Fig. $2 \mathrm{~B}$ ). If, as predicted through bioinformatics, $\Delta$ FosB is only phosphorylated
A

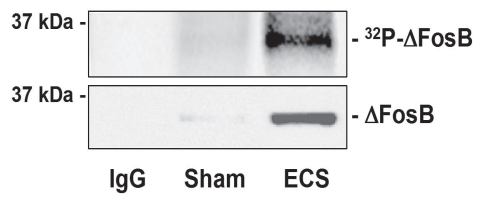

B
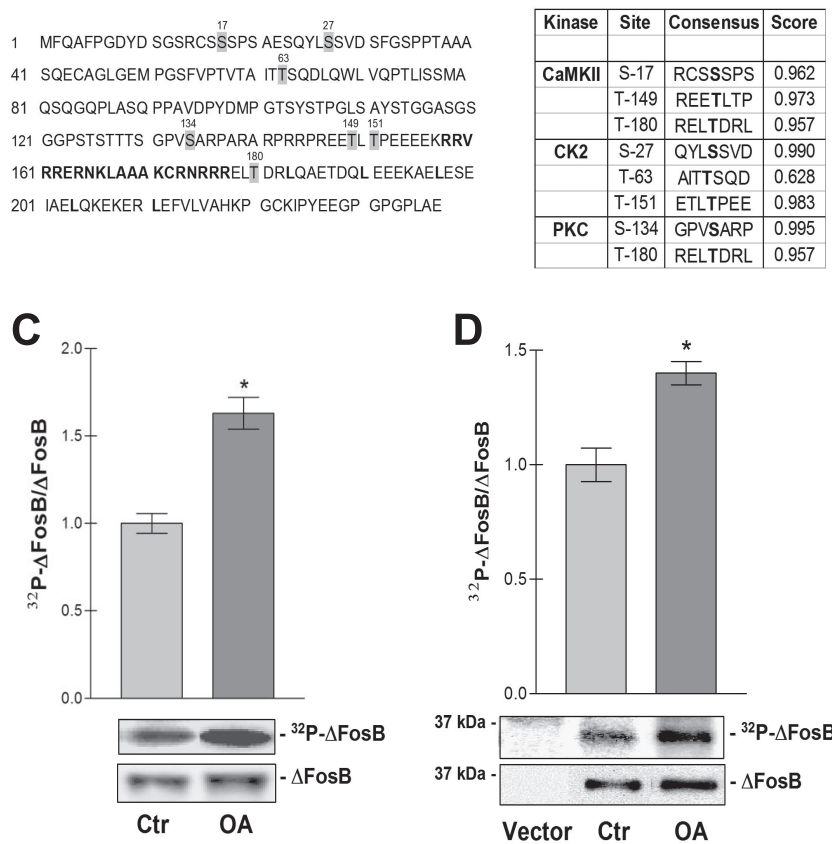

Figure 2. $\quad \Delta F$ Fos $B$ is a phosphoprotein in brain. $A, \Delta F$ osB is phosphorylated in brain. Endogenous $\triangle F$ FosB was induced in rat brain by chronic ECS treatment as described in Materials and Methods. Frontal cortical slices were metabolically labeled with ${ }^{32} \mathrm{P}_{-} \mathrm{H}_{3} \mathrm{PO}_{4}$ for several hours. After homogenization of the slices, $\triangle F$ FosB was immunoprecipitated, and phosphorylated $\Delta$ FosB ( ${ }^{32} \mathrm{P}-\Delta \mathrm{FosB}$ ) was detected by autoradiography (top panel). Total $\Delta$ FosB in nonradioactive immunoprecipitates was detected by immunoblotting (bottom panel). As negative controls, the immunoprecipitate of a sham-treated animal and nonimmune $\lg G$ are shown. $\boldsymbol{B}$ Candidate phosphorylation sites and kinases with corresponding prediction scores for the mouse $\Delta \mathrm{Fos} B$ protein sequence were obtained by bioinformatic analysis. The candidate sites with the higher prediction scores are highlighted in the protein sequence and listed in the table. The DNA-binding (basic) domain and leucine zipper are in bold in the protein sequence. $C, D$, $\Delta$ FosB phosphorylation is increased by the Ser/Thr phosphatase inhibitor OA. C, ${ }^{32} \mathrm{P}-\Delta$ FosB levels in immunoprecipitates from frontal cortical slices labeled in the absence (Ctr) or presence of $100 \mathrm{ng} / \mathrm{ml}$ OA (graph and top panel) were detected by autoradiography. The bottom panel shows total $\triangle$ FosB detected in immunoprecipitates from unlabeled slices by immunoblotting. D, PC12 cells were infected with HSV- $\triangle$ FosB or HSV-LacZ (vector) and metabolically labeled with ${ }^{32} \mathrm{P}_{-} \mathrm{H}_{3} \mathrm{PO}_{4}$ in the absence (Ctr) or presence of $100 \mathrm{ng} / \mathrm{ml} \mathrm{OA}$. ${ }^{32} \mathrm{P}-\Delta$ FosB levels in immunoprecipitates were detected by autoradiography (graph, top panel). The bottom panel shows total $\Delta$ FosB detected in cell lysates by immunoblotting.

on Ser or Thr residues, then its phosphorylation should be significantly modulated by the activity of Ser/Thr phosphatases. To test this hypothesis, we labeled frontal cortical slices with ${ }^{32} \mathrm{P}$ orthophosphate in the presence or absence of OA, a Ser/Thr protein phosphatase inhibitor. As shown in Figure 2C, OA caused a large $(\sim 2.5$-fold $)$ increase in ${ }^{32} \mathrm{P}-\Delta \mathrm{FosB}$. It also caused a small increase in total $\Delta$ FosB levels, which is consistent with previous reports linking the carcinogenic effects of OA to its ability to induce several immediate early genes including Fos proteins (Miller et al., 1998; Choe et al., 2004). The net result is a significant overall increase $(\sim 60 \%)$ in phosphorylated $\Delta$ FosB levels. 
We then investigated whether, in PC12 cells, which are more amenable to experimental manipulation, $\Delta$ FosB showed a phosphorylation pattern similar to that seen in brain. We expressed $\Delta$ FosB in PC12 cells via infection with HSV $-\Delta$ FosB and metabolically labeled the cells with ${ }^{32} \mathrm{P}$-orthophosphate in the presence or absence of OA. The successful expression and immunoprecipitation of the protein from HSV- $\Delta$ FosB-infected cells is shown by the presence both in the immunoblot (Fig. 2D, bottom panel) and the autoradiograph (top panel) of a $\sim 35 \mathrm{kDa}$ band, absent in the vector-infected cells. As observed in brain, OA caused a small increase in total $\Delta$ FosB levels but a much higher (approximately twofold) increase in ${ }^{32} \mathrm{P}-\Delta \mathrm{FosB}$, resulting in a significant $(\sim 50 \%)$ net increase in $\Delta$ FosB phosphorylation. Furthermore, consistent with the bioinformatic predictions, treatment of PC12 cells with a Tyr phosphatase inhibitor did not result in significant changes in ${ }^{32} \mathrm{P}-\Delta$ FosB levels (data not shown). Together, these findings revealed that $\Delta$ FosB is phosphorylated on Ser and/or Thr residues in brain and in PC12 cells and confirmed the latter to be a good cell culture system in which to further study the phosphorylation and degradation profiles of $\Delta$ FosB.

\section{CK2 but not PKC or CaMKII phosphorylates $\Delta$ FosB in vitro}

As described above, analysis of $\Delta$ FosB amino acid sequence revealed high prediction scores for CK2, PKC, and CaMKII phosphorylation sites. To determine which of these kinases may phosphorylate $\Delta$ FosB, we conducted a series of in vitro phosphorylation reactions using purified kinases and purified recombinant $\Delta$ FosB. As shown in Figure $3 A$, of the three candidate kinases, only CK2 phosphorylated $\Delta$ FosB in a significant manner. In addition, several other kinases were tested (e.g., GSK3 and p70S6K) but failed to significantly phosphorylate $\Delta$ FosB (data not shown). Additional characterization of the CK2 reaction by time course analysis revealed that this kinase can catalyze the incorporation of $\sim 0.5 \mathrm{~mol}$ of phosphate per mole of $\Delta$ FosB (Fig. $3 B)$. The fact that CK2 can phosphorylate $\Delta$ FosB in vitro to a considerable stoichiometry $(\sim 50 \%)$ is suggestive of a physiologically relevant reaction. We then studied the kinetics of this reaction by incubating CK2 in the presence of increasing amounts of purified $\Delta$ FosB, and we determined that CK2 phosphorylates $\Delta$ FosB with a $V_{\max }$ of $5.8 \mathrm{pmol} \cdot \mathrm{min}^{-1} \cdot \mu \mathrm{g}^{-1}$ of enzyme, a $K_{\mathrm{M}}$ of $18.4 \mu \mathrm{M}$, and a $k_{\text {cat }}$ of $0.2 / \mathrm{s}$ (Fig. $3 C$ ). The values obtained for these kinetic parameters further support the physiological relevance of this reaction. For instance, the $K_{\mathrm{M}}$ of CK2 for DARPP32, one of its best known substrates, is $3.4 \mu \mathrm{M}$, and the $k_{\text {cat }}$ is $\sim 0.3 / \mathrm{s}$ (Girault et al., 1989); the $K_{\mathrm{M}}$ for ATP ranges from $\sim 10-40 \mu \mathrm{M}$ (Cochet et al., 1983; Silva-Neto et al., 2002), and that for casein ranges from 10-50 $\mu \mathrm{M}$ (Meggio et al., 1977; Pyerin et al., 1987). Together, these data indicate that $\Delta$ FosB is a bona fide substrate for CK2 in vitro.

\section{CK2 modulates the phosphorylation and stability of $\Delta$ FosB in intact cells}

To assess the physiological relevance of CK2-mediated phosphorylation of $\Delta$ FosB, we conducted comparative phosphopeptide mapping using in vitro phosphorylated and PC12-cellphosphorylated $\triangle$ FosB. After SDS-PAGE and gel elution of ${ }^{32} \mathrm{P}-\Delta$ FosB (from the in vitro reactions or from the immunoprecipitate of ${ }^{32} \mathrm{P}$-labeled cells), the protein was digested with trypsin, and the resulting phosphopeptides were subjected to twodimensional separation. This analysis revealed that the main phosphopeptide from the CK2 reaction comigrated with one of two major phosphopeptides from $\Delta$ FosB phosphorylated in PC12 cells (Fig. 4A), whereas the phosphopeptides resulting

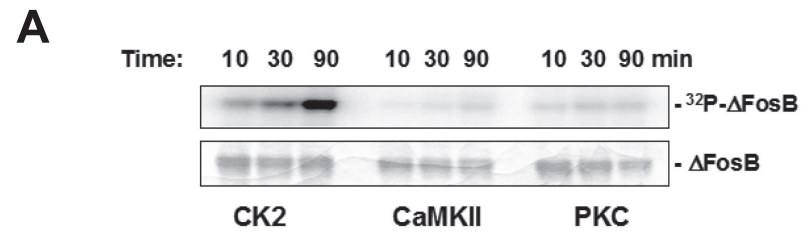

B
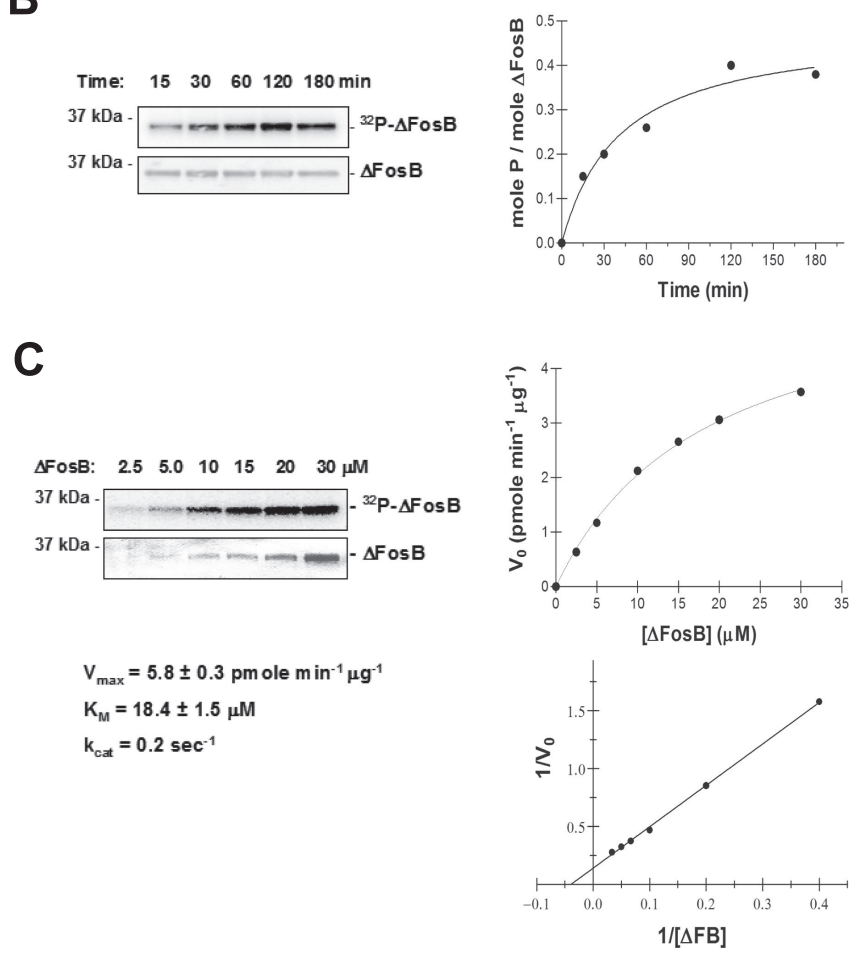

Figure 3. CK2 but not PKC or CaMKII phosphorylates $\Delta$ FosB in vitro. The autoradiograph (top panel) shows the phosphorylated product, and the Coomassie-stained gel (bottom panel) shows total $\Delta$ FosB present in the reaction. $A$, Purified recombinant $\Delta$ FosB was subjected to in vitro phosphorylation by various candidate kinases (three of which are shown). $\boldsymbol{B}$, Time course and stoichiometric analyses indicate that CK2 can phosphorylate $\Delta$ FosB in vitro with a stoichiometry of $\sim 50 \%$. C, Kinetic analysis of the CK2 reaction revealed that $\Delta \mathrm{Fos} B$ is a bona fide in vitro substrate. The linearization of the reaction is shown in a double-reciprocal plot (bottom), but the kinetic parameters were derived from the Michaelis-Menten curve (top).

from the PKC or CaMKII (data not shown) reaction did not. There was a second $\Delta$ FosB phosphopeptide present in the map from PC12 cells, but because of the inability of any of the kinases we have tested to generate a similar phosphopeptide in vitro, we do not presently know whether this second phosphopeptide contains a phosphorylation site different from the other phosphopeptide or whether it represents a distinct tryptic peptide containing the same phosphorylation site.

To further address the physiological relevance of CK2 as a $\Delta$ FosB kinase, we treated $\Delta$ FosB-expressing PC12 cells with two drugs that modulate CK2 activity. As shown in Figure $4 B, \Delta$ FosB phosphorylation was decreased by treatment of PC12 cells with the cell-permeable CK2 inhibitor DRB (Meggio et al., 1990; Szyszka et al., 1995), and increased by treatment with the polyamine spermine, known to be a potent CK2 activator (Cochet and Chambaz, 1983; Meggio et al., 1983). In contrast, treatment of PC12 cells with the PKC inhibitor calphostin-C (Kobayashi et al., 1989; Tamaoki et al., 1990) or the PKC activator PMA (Schmidt and Hecker, 1975; Beh et al., 1989) did not result in significant changes in $\Delta$ FosB phosphorylation. In the case of $\mathrm{PMA}$, the slight (and not significant) increase in ${ }^{32} \mathrm{P}-\Delta \mathrm{FosB}$ could 
A

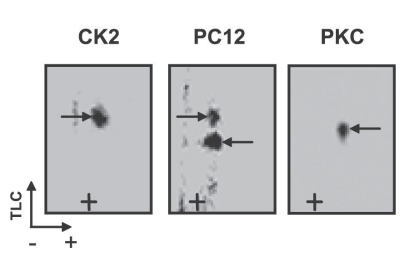

C

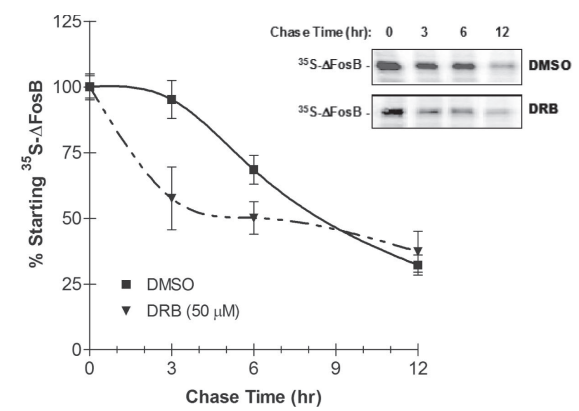

D

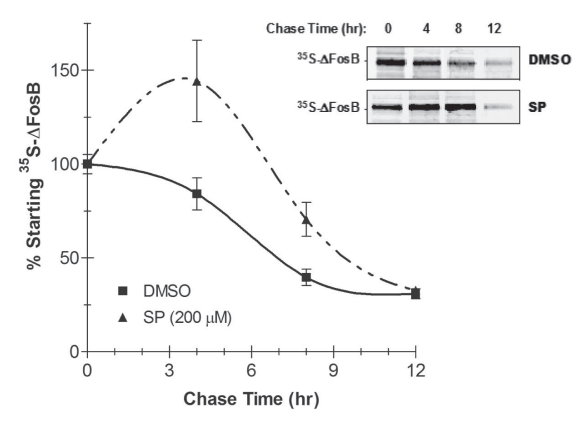

E

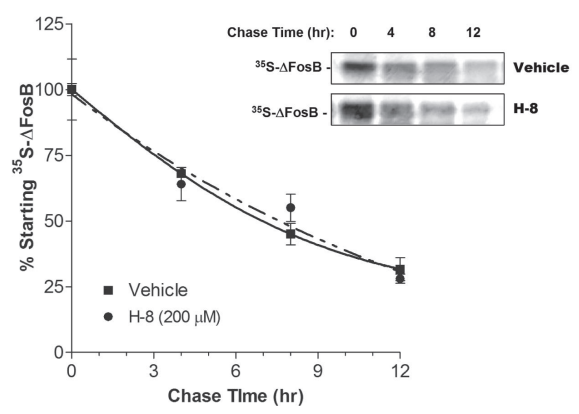

$\mathbf{F}$

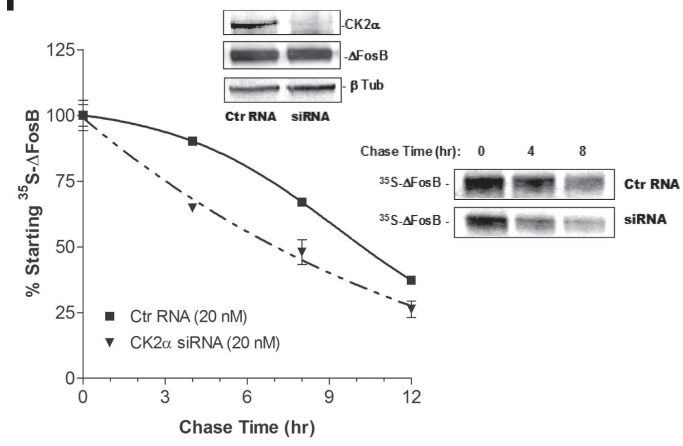

Figure 4. CK2 modulates the phosphorylation and stability of $\Delta$ FosB in intact cells. $A$, CK2 but not PKC seems to phosphorylate $\Delta$ FosB in cells. Two-dimensional phosphopeptide maps of $\Delta$ FosB phosphorylated by CK2 or PKC in vitro or by intact PC12 cells. The arrows show the comigration of the CK2-phosphorylated peptide but not the PKC-phosphorylated one with one of the $\Delta$ FosB phosphopeptides obtained from $\mathrm{PC} 12$ cells. $B, \Delta$ FosB phosphorylation in $\mathrm{PC} 12$ cells is increased by treating cells with the potent CK2 activator spermine (SP) and decreased by treatment with the CK2 inhibitor DRB. In contrast, $\triangle$ FosB phosphorylation in PC12 cells was not affected by treatment with either a PKC activator (PMA) or the PKC-specific inhibitor calphostin-C (Calph). A representative autoradiogram (top panel) and immunoblot (bottom panel) are shown. $C-F$, Effect of CK2 activity on $\Delta$ FosB stability. The figures show the time course (and representative autoradiogram) of $\Delta$ FosB degradation. PC12 cells transiently expressing $\triangle F$ osB were subjected to pulse-chase experiments conducted in the absence or presence of the $(K 2$ inhibitor DRB ( $)$, the CK2 activator spermine $(\boldsymbol{D})$, or the broad-spectrum kinase inhibitor $\mathrm{H}-8(\boldsymbol{E})$, which was used to control for the nonspecific effects of DRB. $\boldsymbol{F}$, Effect of knocking down the catalytic subunit of $\mathrm{CK2}$ on $\Delta$ FosB stability. PC12 cells were transfected with either a nontargeting siRNA (Ctr) or siRNA targeting rat CK2 $\alpha$ and $24 \mathrm{~h}$ later transfected with a $\Delta$ FosB plasmid. The top panel depicts immunoblots of whole-cell lysates showing the effect of the CK2 siRNA on CK2 and $\Delta$ FosB protein levels. The corresponding immunoblot for $\beta$-tubulin is shown as a loading control.

be accounted for by an increase in total $\Delta$ FosB levels caused by this drug; in fact, it has been reported that phorbol esters induce expression of several Fos family proteins, including FosB (Yoza et al., 1992; Suh et al., 2004). Furthermore, treatment of cells with the specific cell-permeable CaMKII inhibitor m-AIP (Ishida and Fujisawa, 1995; Stevens et al., 1999) also did not result in decreased $\Delta$ FosB phosphorylation (data not shown). Together, these results are consistent with our in vitro findings and indicate that in intact cells $\Delta$ FosB is likely phosphorylated by CK2 but not PKC or CaMKII. The fact that CK2 inhibition does not completely prevent $\Delta$ FosB phosphorylation indicates the existence of additional phosphorylation sites in the protein.

We next examined whether CK2 plays a role in the turnover of $\Delta$ FosB and thereby in its stability. To this end, we conducted pulse-chase experiments using $\Delta$ FosB-expressing $\mathrm{PC} 12$ cells treated with either the $\mathrm{CK} 2$ inhibitor or the $\mathrm{CK} 2$ activator used in the phosphorylation study. As shown in Figure 4C, treatment of cells with the CK2 inhibitor DRB had a significant effect on the turnover rate of $\Delta \mathrm{FosB}$, evidenced by the change in shape of its degradation curve, from biphasic to a curve that is closer to that of an exponential decay. Conversely, the presence of the CK2 activator spermine caused a significant decrease in the degradation rate of $\Delta$ FosB, which led to the accumulation of the protein during the first hours of the chase (Fig. 4D).

As is the case with many kinase activators and inhibitors, spermine and DRB can have metabolic effects outside the mod- ulation of CK2 activity. In fact, DRB has been shown to inhibit the transcription factor IIH (TFIIH)-associated kinase (Yankulov et al., 1995), which results in inhibition of RNA polymerase II-mediated transcription. Because this effect could conceivably affect the stability of $\Delta$ FosB, we analyzed the effect of the broad spectrum kinase inhibitor H-8 (Hidaka and Kobayashi, 1992) on $\Delta$ FosB turnover at a concentration $(200 \mu \mathrm{M})$ known to inhibit TFIIH-associated kinase but not CK2 (Yankulov et al., 1995). As shown in Figure $4 E$, treatment with $\mathrm{H}-8$ did not affect the turnover rate of $\Delta$ FosB. Similar results were obtained with H-7, another broad spectrum kinase inhibitor, used at a concentration that inhibits TFIIH-associated kinase but not CK2 (data not shown). These data further support the interpretation that the reduction in $\triangle$ FosB stability caused by DRB is most likely attributable to inhibition of CK2.

To further establish the role of CK2 in $\Delta$ FosB turnover, we investigated the consequences of knocking down CK2 via siRNA. We performed these experiments using PC12 cells that were first transfected with control (nontargeting) siRNA or an siRNA that targets the mRNA of the catalytic subunit of rat CK2 (CK2 $\alpha)$ and $24 \mathrm{~h}$ later transfected with $\Delta$ FosB. As shown in Figure $4 F$, transfection with the CK2 $\alpha$ siRNA efficiently and specifically knocked down CK $2 \alpha$ protein levels without affecting $\Delta$ FosB levels (top panel). Pulse-chase analysis revealed that knocking down CK2 resulted in a significant increase in $\Delta$ FosB turnover rate as evidenced by the faster degradation of the protein. The fact that 
A

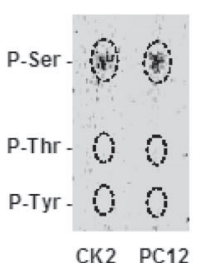

B

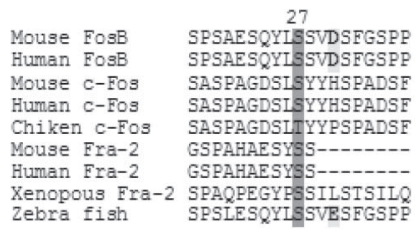

C

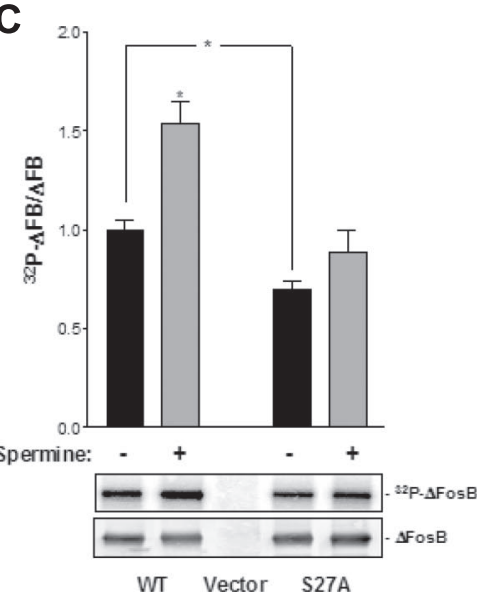

Figure 5. CK2 Phosphorylates $\Delta$ FosB on Ser27. $\boldsymbol{A}$, Phosphoamino acid analysis of CK2-phosphorylated (in vitro) and PC12 cell-phosphorylated $\Delta$ FosB showing that, in both cases, the major residue phosphorylated is serine. $\boldsymbol{B}$, Cross-species analysis of FosB/ $\Delta$ FosB amino acid sequence revealed high conservation of Ser 27 among Fos family members from human to zebrafish (dark highlight). However, the acidic residue at position +3 , which is required for the CK2 consensus site, is not conserved (light highlight). $C$, HeLa cells were transiently transfected with either wild-type $\Delta \mathrm{FosB}$ (WT) or $\Delta \mathrm{FosB}$ containing a point mutation to substitute Ser27 with Ala (S27A). Cells were metabolically labeled with ${ }^{32} \mathrm{P}_{-} \mathrm{H}_{3} \mathrm{PO}_{4}$ and treated with vehicle or with spermine (SP) to activate CK2. A representative autoradiogram (top panel) and immunoblot (bottom panel) of the obtained $\Delta$ FosB immunoprecipitates are shown. The immunoprecipitate of mock-transfected cells (vector) is shown.

A

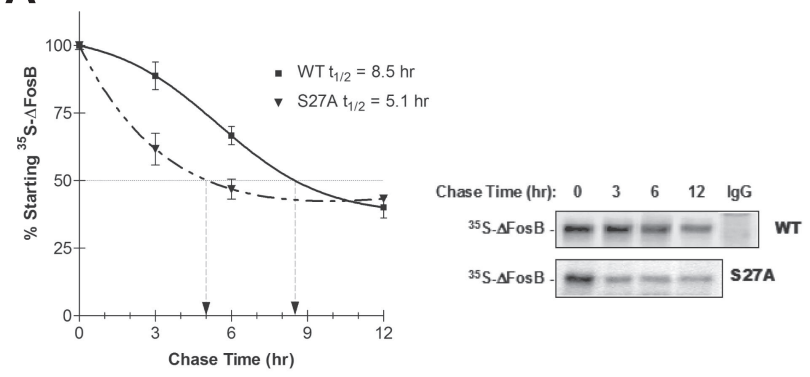

B

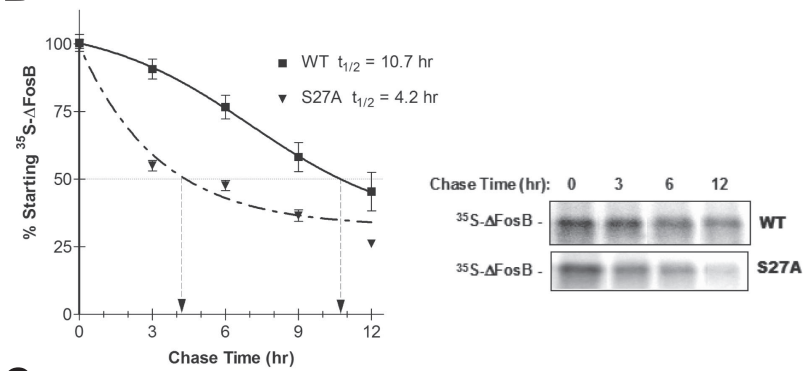

c

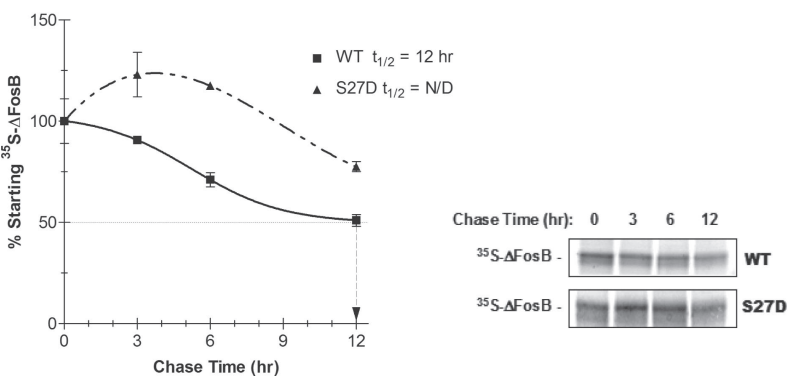

Figure 6. Phosphorylation of Ser27 regulates the stability of $\Delta$ FosB. A, C, Pulse-chase analysis showing the effect of Ser27 phosphorylation on the turnover rate of $\Delta$ FosB. The degradation profile and estimated half-lives of wild-type $\Delta$ FosB (WT), the Ser27 to Ala mutant (S27A), and the phosphomimetic Ser27 to Asp mutant (S27D) are shown. The same findings were obtained in HeLa cells $(\boldsymbol{A})$ and PC12 cells $(\boldsymbol{B}, \boldsymbol{C})$. inhibiting CK2 activity (whether via DRB treatment or siRNA) increases the turnover of $\Delta \mathrm{FosB}$ and results in the disappearance of the slow-rate component of the biphasic curve, whereas CK2 activation enhances the slow phase of the curve, provides strong support for the idea that CK2 plays a role in regulating $\Delta \mathrm{FosB}$ stability.

\section{CK2 phosphorylates $\Delta$ FosB on Ser27}

To begin to identify the site(s) on $\Delta$ FosB phosphorylated by CK2, we conducted phospho-amino acid analysis of recombinant $\Delta$ FosB phosphorylated by CK2 in vitro and of $\Delta$ FosB phosphorylated in PC12 cells. These experiments revealed that, in both cases, the only phosphoamino acid detected was phospho-Ser (Fig. 5A). This finding, together with the stoichiometry obtained for the CK2 in vitro phosphorylation reaction $(\sim 50 \%)$ (Fig. $3 B$ ) and the presence of only one significant spot on the CK2 phosphopeptide map (Fig. $4 A$ ), suggests that CK2 phosphorylation of $\triangle \mathrm{FosB}$ is probably limited to a single serine residue. This conclusion is consistent with the phosphorylation consensus site analysis (Fig. $2 B$ ), which predicted only one candidate serine, i.e., Ser27, for CK2. Taxonomic analysis revealed that Ser27 is highly conserved through evolution among Fos family members (Fig. $5 B$ ), suggesting that it may bear an important physiological function.

To determine whether Ser27 is phosphorylated in $\Delta$ FosB, we mutated this residue to Ala, and analyzed the consequences on the phosphorylation status of the protein. To this end, we used HeLa cells (which can be transfected with higher efficiency) to transiently express either WT or S27A mutant $\Delta$ FosB. Approximately $24 \mathrm{~h}$ after transfection, the cells were metabolically labeled with ${ }^{32} \mathrm{P}$-orthophosphate, and whole-cell lysates were prepared. Following immunoprecipitation and SDS-PAGE, ${ }^{32} \mathrm{P}-\Delta$ FosB was detected by autoradiography and total $\Delta$ FosB by immunoblotting. As shown in Figure $5 C$ (bottom panel), $\Delta$ FosB was not detected in the vector-transfected cells, whereas cells transfected with either WT or S27A mutant $\Delta$ FosB successfully expressed the protein. We found that the S27A mutation caused a significant $(\sim 30 \%)$ reduction in ${ }^{32} \mathrm{P}-\Delta$ FosB levels (Fig. $5 \mathrm{C}$, top panel and graph), indicating that in living cells, $\Delta \mathrm{FosB}$ is phosphorylated on Ser27. In an effort to establish whether in cells Ser27 is indeed phosphorylated by CK2, we compared the ability of the CK2 activator spermine to modulate the phosphorylation of WT and S27A $\triangle$ FosB. As we had observed previously in PC12 cells (Fig. $4 B$ ), treatment of $\mathrm{HeLa}$ cells with spermine significantly increased phosphorylation of the WT protein. The fact that this effect was significantly diminished by the S27A mutation (Fig. $5 C$ ) supports the interpretation that Ser27 in $\Delta$ FosB is a physiological substrate for CK2.

\section{Phosphorylation of Ser27 regulates stability of $\Delta$ FosB}

Having established that the stability of $\triangle F$ FosB is decreased when CK2 is inhibited and enhanced when CK2 is activated (Fig. 4), and that CK2 phosphorylates $\Delta$ FosB on Ser27 (Fig. 5), we predicted that preventing phosphorylation of this site should destabilize the protein. Pulse-chase experiments conducted with HeLa cells transiently expressing either WT or S27A mutant $\Delta$ FosB 
A

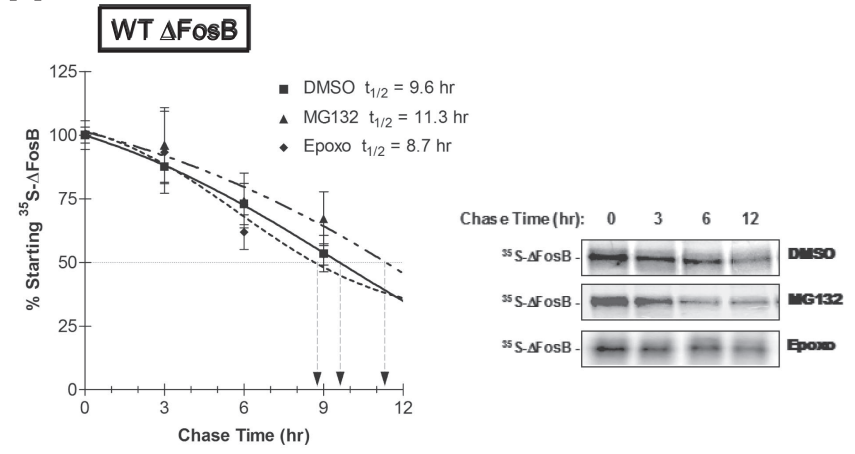

B

S27A $\Delta$ FosB

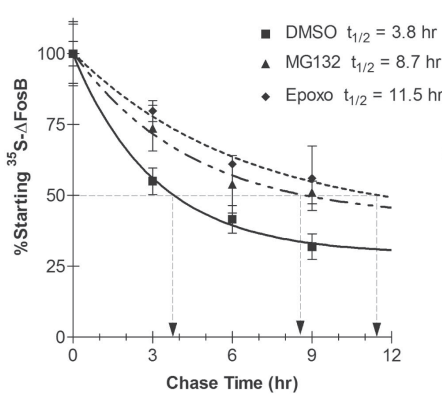

Chase Time (hr): $\quad \begin{array}{llll}0 & 3 & 6 & 12\end{array}$
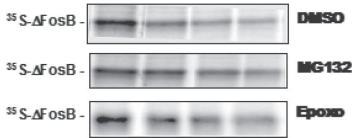

C
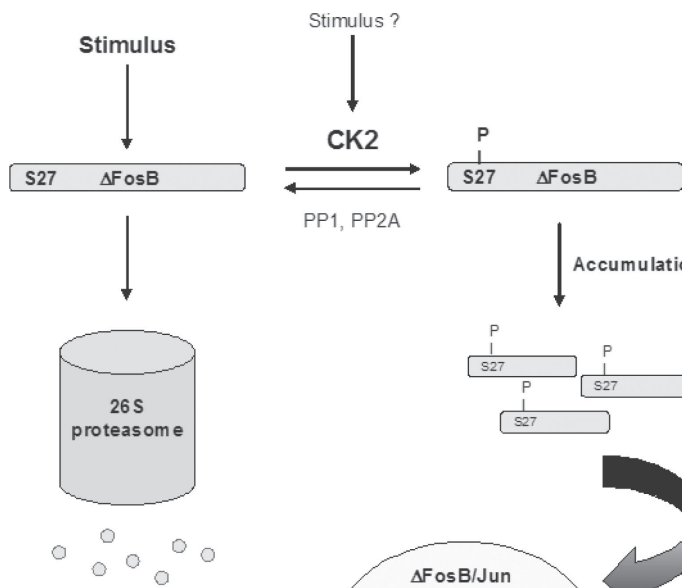

PP1, PP2A
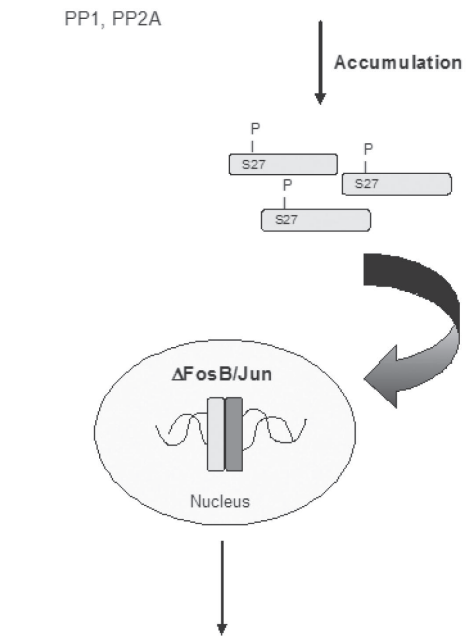

Stable Changes in Gene Expression

$$
\downarrow
$$

Stable Behavioral Adaptations

Figure 7. Phosphorylation of Ser27 stabilizes $\Delta$ FosB by preventing its proteasomal degradation. $\boldsymbol{A}, \boldsymbol{B}$, Pulse-chase analysis with HSV-infected PC12 cells showing the degradation profile and estimated half-lives of wild-type $\Delta \operatorname{FosB}(\boldsymbol{A})$ or $\mathrm{S27A} \Delta \mathrm{FosB}(\boldsymbol{B})$ in the absence or presence of either of two proteasome inhibitors [MG132 and epoxomicin (Epoxo)]. Note the fact that revealed that, as predicted, the S27A mutation resulted in a significant increase in the rate of degradation of $\triangle \mathrm{FosB}$, and a concomitant decrease in the half-life of the protein (Fig. 6A). We then investigated whether this regulatory mechanism also occurs in the more neuron-like PC12 cell line. These experiments revealed that, as we had observed in HeLa cells, the S27A point mutation causes a dramatic decrease in the half-life of $\Delta$ FosB in PC12 cells (from $\sim 11$ to $\sim 4$ h) (Fig. $6 B$ ). The fact that this destabilization is similar to that caused by CK2 inhibition or knock-down (Fig. 4) provides further support for the idea that CK2-mediated phosphorylation of Ser27 regulates the stability of $\Delta$ FosB. Additional evidence for the regulatory role of Ser27 phosphorylation on $\Delta$ FosB protein turnover was obtained using a phosphomimetic Ser27 to Asp mutation (S27D). The S27D mutation is considered phosphomimetic, because it places a large negatively charged (carboxyl) group at amino acid 27 and thereby partly mimics the phosphorylation of Ser27. As shown in Figure 6C, the S27D mutation caused the opposite effect of the S27A mutation and resulted in a protein significantly more stable than the WT protein. Similarly to the effect obtained after CK2 activation (Fig. $4 D$ ), the S27D mutation resulted in the accumulation and thus increased $\Delta$ FosB levels during the first hours of chase.

\section{Ser27 phosphorylation stabilizes $\Delta$ FosB by preventing its proteasomal degradation}

To begin elucidating the mechanism by which phosphorylation of Ser27 stabilizes $\Delta$ FosB, we examined the ability of the proteasome inhibitors MG132 (Palombella et al., 1994; Tsubuki et al., 1996) and epoxomicin (Hanada et al., 1992; Kim et al., 1999) to modulate the degradation rate of WT and S27A mutant $\triangle$ FosB. Pulse-chase experiments were conducted using PC12 cells infected with a recombinant HSV expressing either WT or S27A $\triangle F o s B$ and treated with either DMSO or one of the two proteasome inhibitors. These experiments revealed that although the degradation rate of the WT protein is relatively insensitive to the presence of either of the two proteasome inhibitors (Fig. 7A), that of the S27A mutant is sensitive to these drugs (Fig. 7B). This indicates that, unlike the WT protein, the S27A mutant is a target of proteasomal degradation. Indeed, treatment of cells with either MG132 or epoxomicin fully reversed the effect of the S27A mutation on the degradation rate of $\Delta \mathrm{FosB}$, evidenced by an increase in the half-life of the S27A mutant from $\sim 4$ to $\sim 9 \mathrm{~h}$ for MG132 and to $\sim 12 \mathrm{~h}$ for epoxomicin (Fig. $7 B$ ). Together, these findings indicate that phosphorylation of $\Delta$ FosB on Ser27 protects the protein from proteasomal degradation and is therefore essential for its unusual stability.

\section{Discussion}

In the present study, we show that $\Delta$ FosB has a half-life of $\sim 10 \mathrm{~h}$ in cell culture, which makes it stable compared with full-length FosB and most other inducible transcription factors, whose halflives in cell culture can be as short as a few minutes and rarely

$\leftarrow$

neither drug has a significant effect on the turnover of wild-type $\Delta F$ os $B$, whereas treatment of cells with either proteasome inhibitor resulted in the stabilization of $\$ 27 \mathrm{~A} \triangle \mathrm{F}$ osB. C, A model for the role of Ser27 phosphorylation in the ability of $\Delta$ FosB to mediate long-term brain plasticity. Once induced, a portion of $\Delta$ FosB is stabilized in brain by the CK2-mediated phosphorylation of S27. This results in its accumulation, which in turn results in long-lasting changes in gene expression. These stable changes in gene expression contribute to stable behavioral adaptations. Conversely, the dephosphorylation of 27 by the Ser/Thr phosphatases PP1 and/or PP2A results in destabilization of the protein and its processing by the proteasomal machinery. 
exceed 3 h (Hann and Eisenman, 1984; Dobrazanski et al., 1991; Roberts and Whitelaw, 1999; Ferrara et al., 2003; Hirata et al., 2004). In addition, we find that $\Delta$ FosB is phosphorylated in brain and that its phosphorylation is sensitive to the PP1/PP2A inhibitor okadaic acid. Our cell culture studies demonstrate that the stability of $\Delta$ FosB is modulated by CK2, with higher CK2 activity stabilizing the protein. Finally, our findings suggest that CK2 phosphorylates $\Delta$ FosB on a highly conserved $\mathrm{N}$ terminus serine (S27) and demonstrate that phosphorylation of S27 protects $\Delta$ FosB from proteasomal degradation. We therefore propose a model whereby phosphorylation of $\Delta \mathrm{FosB}$ on S27 by CK2 is a critical regulatory mechanism of turnover of $\Delta$ FosB (Fig. $7 C$ ). Such phosphorylation-mediated stabilization of $\Delta$ FosB is functionally important, because increased levels of $\Delta$ FosB in particular brain regions have been shown to directly regulate numerous neuronal genes in vivo and to exert potent behavioral effects in animal models of several neuropsychiatric disorders (see Introduction).

Although phosphorylation is a fast and reversible way of regulating the transcriptional activity of certain transcription factors, such as CREB (cAMP response element binding protein) (Bohmann, 1990), modulating the degradation of transcription factors provides an even more powerful (less easily reversible) form of regulation (Desterro et al., 2000). Transcription factors whose functional activity is regulated at the level of their degradation include NF $\kappa$ B (Desterro et al., 2000), c-Myc (Sears et al., 1999), and c-Fos (Ferrara et al., 2003), among others. In many instances, phosphorylation is a key regulator of the stability of a transcription factor, as has been shown for c-Fos (Okazaki and Sagata, 1995; Tsurumi et al., 1995), Fos-related antigen-1 (Fra-1) (Vial and Marshall, 2003), Fra-2 (Manabe et al., 2001), c-Jun (Fuchs et al., 1996), JunB (Fuchs et al., 1997), ATF2 (Fuchs et al., 2000), and p53 (Buschmann et al., 2001). Our studies thus add $\Delta$ FosB to this list of transcription factors whose functional activity is regulated through its phosphorylated-dependent stability.

CK2 is a ubiquitous and constitutively active Ser/Thr kinase that has $>300$ purported substrates identified thus far and is implicated in multiple biological processes, including cell death and survival (Litchfield, 2003; Unger et al., 2004), cellular stress responses (Yanagawa et al., 1997; Kato et al., 2003), and DNA repair and chromatin remodeling (Barz et al., 2003; Krohn et al., 2003). More than one-third of the putative substrates of CK2 are proteins involved in the regulation of gene expression (Meggio and Pinna, 2003). In fact, CK2 has been shown to be a prominent nuclear kinase (Krek et al., 1992) (for review, see Yu et al., 2001) and to interact with the bZIP domains of several transcription factors (Yamaguchi et al., 1998). CK2-mediated phosphorylation has also been shown to modulate the degradation (either enhancing or decreasing it) of many proteins, including IkB (Schwarz et al., 1996), PTEN (Torres and Pulido, 2001), lens connexin (Yin et al., 2000), chromatin-associated protein HMG1 (Wisniewski et al., 1999), and several transcription factors such as HMGB (Stemmer et al., 2002), Myf-5 (Winter et al., 1997), and c-Myc (Channavajhala and Seldin, 2002). CK2 is most abundant in brain (Alcazar et al., 1988; Girault et al., 1990), and its activity has been implicated in many aspects of brain function, including neuronal survival (Boehning et al., 2003), differentiation (Nuthall et al., 2004), ion channel function (Jones and Yakel, 2003; Bildl et al., 2004), and long-term potentiation and neuronal plasticity (Diaz-Nido et al., 1992; Lieberman and Mody, 1999; Reikhardt et al., 2003).

Despite this growing evidence for the role of CK2 in the regulation of neuronal function, little is known about what controls its activity. CK2 is thought to be constitutively active, with regu- lation of its ability to phosphorylate specific substrates relying mostly on changes in its intracellular localization (e.g., cytosol vs nucleus) (Ahmed and Tawfic, 1994; Yu et al., 1999). This information raises an important question concerning what signals are required to induce $\Delta$ FosB accumulation in brain after chronic stimulation (Fig. $7 C$ ). One requirement is repeated activation of the fos $B$ gene and induction of $\Delta$ FosB mRNA (Chen et al., 1995). Our data indicate that CK2 phosphorylation of $\Delta$ FosB is critical for its stability, suggesting that a second signal may be required for the long-term effects of $\Delta$ FosB on gene expression, namely, a signal that stimulates the phosphorylation of protein by CK2. This could involve the activation of CK2 by some unknown mechanism or its translocation to the nucleus. Alternatively, CK2 phosphorylation of $\Delta$ FosB may be constitutive, such that as $\Delta$ FosB protein is translated in response to each stimulus, a portion of it gets phosphorylated and thereby stabilized, so that with repeated stimulation it accumulates to high levels in affected neurons.

Our findings show that CK2 and S27 are probably not the only kinase and site responsible for $\Delta$ FosB phosphorylation, because neither inhibition of CK2 nor the S27A mutation were able to completely prevent $\Delta \mathrm{FosB}$ phosphorylation. By the same token, the fact that the S27A mutation results in a $30 \%$ reduction in phospho- $\Delta$ FosB argues that S27 is a major phosphorylation site on the protein. We are, nevertheless, investigating other putative kinases and phosphorylation sites on $\Delta$ FosB. Ultimately, it will be important as well to analyze the phosphorylation of S27 and any other phosphorylation sites in $\Delta$ FosB in brain in vivo after various types of chronic stimulation, for example, through the use of mass spectrometry or phosphospecific antibodies.

As mentioned above, S27 in $\Delta$ FosB is highly conserved throughout evolution and among other Fos family proteins. However, the consensus site for CK2 is not: as shown in Figure $5 B$, only FosB $/ \Delta$ FosB (and the Zebrafish xenolog), but not c-Fos or Fra-2, possess an acidic residue at +3 , a key determinant of CK2 phosphorylation (Marin et al., 1986; Meggio et al., 1994). Thus, the lack of CK2 phosphorylation on S27 may explain why other Fos family proteins are not as stable as $\Delta$ FosB. However, this does not explain why full-length FosB, which has the same CK2 consensus site as $\Delta$ FosB, is not similarly stabilized. We do not know whether full-length FosB is phosphorylated by CK2 on this conserved residue. The only reports of FosB (Skinner et al., 1997) and c-Fos (Okazaki and Sagata, 1995; Chen et al., 1996) phosphorylation describe sites in the C-terminal region of these proteins, which is absent in $\Delta$ FosB. The potential phosphorylation of full-length FosB and other Fos family proteins by CK2 requires direct investigation. However, even if they are phosphorylated, the other Fos family proteins are known to contain motifs at their $\mathrm{C}$ termini that target the proteins for rapid degradation (Papavassiliou et al., 1992; Jariel-Encontre et al., 1997; Acquaviva et al., 2002). For example, it has been shown that a stretch of $\sim 21$ residues present in the $\mathrm{C}$ terminus of all Fos family proteins, but absent in $\Delta \mathrm{FosB}$, acts as a destabilizing domain for c-Fos (Acquaviva et al., 2001). We found that although this sequence similarly destabilizes full-length FosB (Carle et al., 2004), the absence of this domain in $\Delta$ FosB does not fully account for its stabilization. Rather, the combination of the absence of this $\mathrm{C}$ terminus domain and Ser27 phosphorylation seems to fully account for the approximately fivefold difference in stability between $\Delta$ FosB and FosB.

Although the degradation of Fos family proteins is complex and not fully understood, proteasomal degradation seems to be the major pathway involved (Salvat et al., 1999; Acquaviva et al., 
2002; Ferrara et al., 2003). Data presented here, in which proteasomal inhibitors do not significantly alter the rate of $\Delta$ FosB degradation, argue that, unlike other Fos family proteins, $\Delta$ FosB evades the $26 \mathrm{~S}$ proteasome, and this plays a central role in its stabilization. We therefore propose a scheme whereby the enhanced stability of $\Delta$ FosB is attributable to the combination of two main factors: (1) the absence of a C-terminal destabilizing domain and (2) the phosphorylation of S27 by CK2.

In summary, the present study provides mechanistic insight as to why $\Delta$ FosB, a product of the immediate early gene fos $B$, is, unlike all other Fos family members, a relatively long-lived protein. Although other Fos family proteins are thought to mediate rapid but transient stimulus-transcription coupling (Morgan and Curran, 1995), the relative stability of $\Delta$ FosB confers on it the ability to mediate longer-lasting transcriptional changes induced by chronic stimulation. This supports the view that $\Delta$ FosB functions as a sustained molecular switch in brain, gradually converting acute responses into chronic adaptations. Identification of Ser27 phosphorylation as a central mechanism for the stability of $\Delta$ FosB opens new avenues for the development of means to regulate the function of $\Delta$ FosB and thereby modulate its long-term effects on neural and behavioral plasticity.

\section{References}

Acquaviva C, Brockly F, Ferrara P, Bossis G, Salvat C, Jariel-Encontre I, Piechaczyk M (2001) Identification of a C-terminal tripeptide motif involved in the control of rapid proteasomal degradation of c-Fos proto-oncoprotein during the G(0)-to-S phase transition. Oncogene 20:7563-7572.

Acquaviva C, Bossis G, Ferrara P, Brockly F, Jariel-Encontre I, Piechaczyk M (2002) Multiple degradation pathways for Fos family proteins. Ann NY Acad Sci 973:426-434.

Ahmed K, Tawfic S (1994) Mechanism of intracellular regulation of protein kinase CK2: role of stimulus-mediated subnuclear association. Cell Mol Biol Res 40:539-545.

Alcazar A, Martin E, Lopez-Fando J, Salinas M (1988) An improved purification procedure and properties of casein kinase II from brain. Neurochem Res 13:829-836.

Andersson M, Westin JE, Cenci MA (2003) Time course of striatal DeltaFosB-like immunoreactivity and prodynorphin mRNA levels after discontinuation of chronic dopaminomimetic treatment. Eur J Neurosci 17:661-666.

Barz T, Ackermann K, Dubois G, Eils R, Pyerin W (2003) Genome-wide expression screens indicate a global role for protein kinase CK2 in chromatin remodeling. J Cell Sci 116:1563-1577.

Beh I, Schmidt R, Hecker E (1989) Two isozymes of PKC found in HL-60 cells show a difference in activation by the phorbol ester TPA. FEBS Lett 249:264-266.

Bildl W, Strassmaier T, Thurm H, Andersen J, Eble S, Oliver D, Knipper M, Mann M, Schulte U, Adelman JP, Fakler B (2004) Protein kinase CK2 is coassembled with small conductance $\mathrm{Ca}(2+)$-activated $\mathrm{K}+$ channels and regulates channel gating. Neuron 43:847-858.

Bing G, Wang W, Qi Q, Feng Z, Hudson P, Jin L, Zhang W, Bing R, Hong JS (1997) Long-term expression of Fos-related antigen and transient expression of delta FosB associated with seizures in the rat hippocampus and striatum. J Neurochem 68:272-279.

Blom N, Sicheritz-Ponten T, Gupta R, Gammeltoft S, Brunak S (2004) Prediction of post-translational glycosylation and phosphorylation of proteins from the amino acid sequence. Proteomics 4:1633-1649.

Boehning D, Moon C, Sharma S, Hurt KJ, Hester LD, Ronnett GV, Shugar D, Snyder SH (2003) Carbon monoxide neurotransmission activated by CK2 phosphorylation of heme oxygenase-2. Neuron 40:129-137.

Bohmann D (1990) Transcription factor phosphorylation: a link between signal transduction and the regulation of gene expression. Cancer Cells 2:337-344.

Buschmann T, Potapova O, Bar-Shira A, Ivanov VN, Fuchs SY, Henderson S, Fried VA, Minamoto T, Alarcon-Vargas D, Pincus MR, Gaarde WA, Holbrook NJ, Shiloh Y, Ronai Z (2001) Jun NH2-terminal kinase phosphorylation of $\mathrm{p} 53$ on Thr-81 is important for $\mathrm{p} 53$ stabilization and transcriptional activities in response to stress. Mol Cell Biol 21:2743-2754.
Carle TL, Ulery PG, Nestler EJ (2004) Absence of a conserved Fos family C-terminal domain contributes to deltaFosB's unique stability. Soc Neurosci Abstr 30:692.2.

Channavajhala P, Seldin DC (2002) Functional interaction of protein kinase CK2 and c-Myc in lymphomagenesis. Oncogene 21:5280-5288.

Chen J, Nye HE, Kelz MB, Hiroi N, Nakabeppu Y, Hope BT, Nestler EJ (1995) Regulation of delta FosB and FosB-like proteins by electroconvulsive seizure and cocaine treatments. Mol Pharmacol 48:880-889.

Chen J, Kelz MB, Hope BT, Nakabeppu Y, Nestler EJ (1997) Chronic Fosrelated antigens: stable variants of $\Delta$ FosB induced in brain by chronic treatments. J Neurosci 17:4933-4941.

Chen RH, Juo PC, Curran T, Blenis J (1996) Phosphorylation of c-Fos at the C-terminus enhances its transforming activity. Oncogene 12:1493-1502.

Choe ES, Parelkar NK, Kim JY, Cho HW, Kang HS, Mao L, Wang JQ (2004) The protein phosphatase 1/2A inhibitor okadaic acid increases CREB and Elk-1 phosphorylation and c-fos expression in the rat striatum in vivo. J Neurochem 89:383-390.

Cochet C, Chambaz EM (1983) Polyamine-mediated protein phosphorylations: a possible target for intracellular polyamine action. Mol Cell Endocrinol 30:247-266.

Cochet C, Feige JJ, Chambaz EM (1983) Catalytic and molecular properties of a highly purified $\mathrm{G}$ type casein kinase from bovine lung tissue. Biochim Biophys Acta 743:1-12.

Colby CR, Whisler K, Steffen C, Nestler EJ, Self DW (2003) Striatal cell type-specific overexpression of DeltaFosB enhances incentive for cocaine. J Neurosci 23:2488-2493.

Daunais JB, Roberts DC, McGinty JF (1993) Cocaine self-administration increases preprodynorphin, but not c-fos, mRNA in rat striatum. NeuroReport 4:543-546.

Desterro JM, Rodriguez MS, Hay RT (2000) Regulation of transcription factors by protein degradation. Cell Mol Life Sci 57:1207-1219.

Diaz-Nido J, Armas-Portela R, Avila J (1992) Increase in cytoplasmic casein kinase II-type activity accompanies neurite outgrowth after DNA synthesis inhibition in NIA-103 neuroblastoma cells. J Neurochem 58:1820-1828.

Di Maira G, Salvi M, Arrigoni G, Marin O, Sarno S, Brustolon F, Pinna LA, Ruzzene M (2005) Protein kinase CK2 phosphorylates and upregulates Akt/PKB. Cell Death Differ 12:668-677.

Dobrazanski P, Noguchi T, Kovary K, Rizzo CA, Lazo PS, Bravo R (1991) Both products of the fos $\mathrm{B}$ gene, FosB and its short form, FosB/SF, are transcriptional activators in fibroblasts. Mol Cell Biol 11:5470-5478.

Ferrara P, Andermarcher E, Bossis G, Acquaviva C, Brockly F, Jariel-Encontre I, Piechaczyk M (2003) The structural determinants responsible for c-Fos protein proteasomal degradation differ according to the conditions of expression. Oncogene 22:1461-1474.

Fuchs SY, Dolan L, Davis RJ, Ronai Z (1996) Phosphorylation-dependent targeting of c-Jun ubiquitination by Jun N-kinase. Oncogene 13:1531-1535.

Fuchs SY, Xie B, Adler V, Fried VA, Davis RJ, Ronai Z (1997) c-Jun NH2 terminal kinases target the ubiquitination of their associated transcription factors. J Biol Chem 272:32163-32168.

Fuchs SY, Tappin I, Ronai Z (2000) Stability of the ATF2 transcription factor is regulated by phosphorylation and dephosphorylation. J Biol Chem 275:12560-12564.

Girault JA, Hemmings Jr HC, Williams KR, Nairn AC, Greengard P (1989) Phosphorylation of DARPP-32, a dopamine- and cAMP-regulated phosphoprotein, by casein kinase II. J Biol Chem 264:21748-21759.

Girault JA, Hemmings Jr HC, Zorn SH, Gustafson EL, Greengard P (1990) Characterization in mammalian brain of a DARPP-32 serine kinase identical to casein kinase II. J Neurochem 55:1772-1783.

Hanada M, Sugawara K, Kaneta K, Toda S, Nishiyama Y, Tomita K, Yamamoto H, Konishi M, Oki T (1992) Epoxomicin, a new antitumor agent of microbial origin. J Antibiot (Tokyo) 45:1746-1752.

Hann SR, Eisenman RN (1984) Proteins encoded by the human c-myc oncogene: differential expression in neoplastic cells. Mol Cell Biol 4:2486-2497.

Hemmings Jr HC, Girault JA, Williams KR, LoPresti MB, Greengard P (1989) ARPP-21, a cyclic AMP-regulated phosphoprotein ( $\mathrm{Mr}=$ $21,000)$ enriched in dopamine-innervated brain regions. Amino acid sequence of the site phosphorylated by cyclic AMP in intact cells and kinetic studies of its phosphorylation in vitro. J Biol Chem 264:7726-7733.

Hidaka H, Kobayashi R (1992) Pharmacology of protein kinase inhibitors. Annu Rev Pharmacol Toxicol 32:377-397.

Hirata H, Bessho Y, Kokubu H, Masamizu Y, Yamada S, Lewis J, Kageyama R 
(2004) Instability of Hes7 protein is crucial for the somite segmentation clock. Nat Genet 36:750-754.

Hiroi N, Graybiel AM (1996) Atypical and typical neuroleptic treatments induce distinct programs of transcription factor expression in the striatum. J Comp Neurol 374:70-83.

Hope B, Kosofsky B, Hyman SE, Nestler EJ (1992) Regulation of immediate early gene expression and AP-1 binding in the rat nucleus accumbens by chronic cocaine. Proc Natl Acad Sci USA 89:5764-5768.

Hope BT, Kelz MB, Duman RS, Nestler EJ (1994a) Chronic electroconvulsive seizure (ECS) treatment results in expression of a long-lasting AP-1 complex in brain with altered composition and characteristics. J Neurosci 14:4318-4328.

Hope BT, Nye HE, Kelz MB, Self DW, Iadarola MJ, Nakabeppu Y, Duman RS, Nestler EJ (1994b) Induction of a long-lasting AP-1 complex composed of altered Fos-like proteins in brain by chronic cocaine and other chronic treatments. Neuron 13:1235-1244.

Ishida A, Fujisawa H (1995) Stabilization of calmodulin-dependent protein kinase II through the autoinhibitory domain. J Biol Chem 270:2163-2170.

Jariel-Encontre I, Salvat C, Steff AM, Pariat M, Acquaviva C, Furstoss O, Piechaczyk M (1997) Complex mechanisms for c-fos and c-jun degradation. Mol Biol Rep 24:51-56.

Jones S, Yakel JL (2003) Casein kinase ii (protein kinase ck2) regulates serotonin 5-ht(3) receptor channel function in ng108-15 cells. Neuroscience 119:629-634.

Kato Jr T, Delhase M, Hoffmann A, Karin M (2003) CK2 is a C-terminal IkappaB kinase responsible for NF-kappaB activation during the UV response. Mol Cell 12:829-839.

Kelz MB, Chen J, Carlezon Jr WA, Whisler K, Gilden L, Beckmann AM, Steffen C, Zhang YJ, Marotti L, Self DW, Tkatch T, Baranauskas G, Surmeier DJ, Neve RL, Duman RS, Picciotto MR, Nestler EJ (1999) Expression of the transcription factor deltaFosB in the brain controls sensitivity to cocaine. Nature 401:272-276.

Kim KB, Myung J, Sin N, Crews CM (1999) Proteasome inhibition by the natural products epoxomicin and dihydroeponemycin: insights into specificity and potency. Bioorg Med Chem Lett 9:3335-3340.

Kobayashi E, Nakano H, Morimoto M, Tamaoki T (1989) Calphostin C (UCN-1028C), a novel microbial compound, is a highly potent and specific inhibitor of protein kinase C. Biochem Biophys Res Commun 159:548-553.

Krek W, Maridor G, Nigg EA (1992) Casein kinase II is a predominantly nuclear enzyme. J Cell Biol 116:43-55.

Krohn NM, Stemmer C, Fojan P, Grimm R, Grasser KD (2003) Protein kinase CK2 phosphorylates the high mobility group domain protein SSRP1, inducing the recognition of UV-damaged DNA. J Biol Chem 278:12710-12715.

Kumar A, Choi K-H, Renthal W, Tsankova NM, Theobald DEH, Truong H-T, Russo SJ, LaPlant Q, Whistler K, Neve RL, Self DW, Nestler EJ (2005) Chromatin remodeling is a key mechanism underlying cocaineinduced plasticity in striatum. Neuron 48:303-314.

Lieberman DN, Mody I (1999) Casein kinase-II regulates NMDA channel function in hippocampal neurons. Nat Neurosci 2:125-132.

Litchfield DW (2003) Protein kinase CK2: structure, regulation and role in cellular decisions of life and death. Biochem J 369:1-15.

Manabe T, Kuramoto N, Nakamichi N, Aramachi K, Baba K, Hirai T, Yoneyama M, Yoneda Y (2001) Degradation of c-Fos protein expressed by $\mathrm{N}$-methyl-D-aspartic acid in nuclear fractions of murine hippocampus. Brain Res 905:34-43.

Mandelzys A, Gruda MA, Bravo R, Morgan JI (1997) Absence of a persistently elevated $37 \mathrm{kDa}$ fos-related antigen and AP-1-like DNA-binding activity in the brains of kainic acid-treated fosB null mice. J Neurosci 17:5407-5415.

Marin O, Meggio F, Marchiori F, Borin G, Pinna LA (1986) Site specificity of casein kinase-2 (TS) from rat liver cytosol. A study with model peptide substrates. Eur J Biochem 160:239-244.

McClung CA, Nestler EJ (2003) Regulation of gene expression and cocaine reward by CREB and DeltaFosB. Nat Neurosci 6:1208-1215.

McClung CA, Ulery PG, Perrotti LI, Zachariou V, Berton O, Nestler EJ (2004) DeltaFosB: a molecular switch for long-term adaptation in the brain. Brain Res Mol Brain Res 132:146-154.

Meggio F, Pinna LA (2003) One-thousand-and-one substrates of protein kinase CK2? FASEB J 17:349-368.
Meggio F, Donella-Deana A, Pinna LA, Moret V (1977) Phosphorylation of casein fractions by rat liver 'phosvitin kinase.' FEBS Lett 75:192-196.

Meggio F, Brunati AM, Pinna LA (1983) Autophosphorylation of type 2 casein kinase TS at both its alpha- and beta-subunits. Influence of different effectors. FEBS Lett 160:203-208.

Meggio F, Shugar D, Pinna LA (1990) Ribofuranosyl-benzimidazole derivatives as inhibitors of casein kinase-2 and casein kinase-1. Eur J Biochem 187:89-94.

Meggio F, Marin O, Pinna LA (1994) Substrate specificity of protein kinase CK2. Cell Mol Biol Res 40:401-409.

Miller C, Zhang M, He Y, Zhao J, Pelletier JP, Martel-Pelletier J, Di Battista JA (1998) Transcriptional induction of cyclooxygenase-2 gene by okadaic acid inhibition of phosphatase activity in human chondrocytes: costimulation of AP-1 and CRE nuclear binding proteins. J Cell Biochem 69:392-413.

Moratalla R, Elibol B, Vallejo M, Graybiel AM (1996) Network-level changes in expression of inducible Fos-Jun proteins in the striatum during chronic cocaine treatment and withdrawal. Neuron 17:147-156.

Morgan JI, Curran T (1995) Immediate-early genes: ten years on. Trends Neurosci 18:66-67.

Nakabeppu Y, Nathans D (1991) A naturally occurring truncated form of FosB that inhibits Fos/Jun transcriptional activity. Cell 64:751-759.

Nestler EJ, Barrot M, Self DW (2001) Delta FosB: a sustained molecular switch for addiction. Proc Natl Acad Sci USA 98:11042-11046.

Neve RL, Howe JR, Hong S, Kalb RG (1997) Introduction of the glutamate receptor subunit 1 into motor neurons in vitro and in vivo using a recombinant herpes simplex virus. Neuroscience 79:435-447.

Nuthall HN, Joachim K, Stifani S (2004) Phosphorylation of serine 239 of Groucho/TLE1 by protein kinase CK2 is important for inhibition of neuronal differentiation. Mol Cell Biol 24:8395-8407.

Okazaki K, Sagata N (1995) The Mos/MAP kinase pathway stabilizes c-Fos by phosphorylation and augments its transforming activity in NIH 3T3 cells. ЕMBO J 14:5048-5059.

Palombella VJ, Rando OJ, Goldberg AL, Maniatis T (1994) The ubiquitinproteasome pathway is required for processing the NF-kappa B1 precursor protein and the activation of NF-kappa B. Cell 78:773-785.

Papavassiliou AG, Treier M, Chavrier C, Bohmann D (1992) Targeted degradation of c-Fos, but not v-Fos, by a phosphorylation-dependent signal on c-Jun. Science 258:1941-1944.

Peakman MC, Colby C, Perrotti LI, Tekumalla P, Carle T, Ulery P, Chao J, Duman C, Steffen C, Monteggia L, Allen MR, Stock JL, Duman RS, McNeish JD, Barrot M, Self DW, Nestler EJ, Schaeffer E (2003) Inducible, brain region-specific expression of a dominant negative mutant of c-Jun in transgenic mice decreases sensitivity to cocaine. Brain Res 970:73-86.

Perrotti LI, Hadeishi Y, Ulery PG, Barrot M, Monteggia L, Duman RS, Nestler EJ (2004) Induction of DeltaFosB in reward-related brain structures after chronic stress. J Neurosci 24:10594-10602.

Persico AM, Schindler CW, O’Hara BF, Brannock MT, Uhl GR (1993) Brain transcription factor expression: effects of acute and chronic amphetamine and injection stress. Brain Res Mol Brain Res 20:91-100.

Ploegh HL, Dunn BM (2000) Post-translational modification: phosphorylation and phosphatases. In: Current protocols in protein science (Dunn BM, ed), pp 13.01-13.02. New York: Wiley and Sons.

Pyerin W, Burow E, Michaely K, Kubler D, Kinzel V (1987) Catalytic and molecular properties of highly purified phosvitin/casein kinase type II from human epithelial cells in culture (HeLa) and relation to ecto protein kinase. Biol Chem Hoppe Seyler 368:215-227.

Reikhardt BA, Kulikova OG, Borisova GY, Aleksandrova IY, Sapronov NS (2003) Status of the "protein kinase CK2-HMG14" system in age-related amnesia in rats. Neurosci Behav Physiol 33:799-804.

Roberts BJ, Whitelaw ML (1999) Degradation of the basic helix-loop-helix/ Per-ARNT-Sim homology domain dioxin receptor via the ubiquitin/proteasome pathway. J Biol Chem 274:36351-36356.

Rost B, Yachdav G, Liu J (2004) The PredictProtein server. Nucleic Acids Res 32:W321-W326.

Rylski M, Kaczmarek L (2004) Ap-1 targets in the brain. Front Biosci 9:8-23.

Sahin B, Kansy JW, Nairn AC, Spychala J, Ealick SE, Fienberg AA, Greene RW, Bibb JA (2004) Molecular characterization of recombinant mouse adenosine kinase and evaluation as a target for protein phosphorylation. Eur J Biochem 271:3547-3555.

Salvat C, Aquaviva C, Jariel-Encontre I, Ferrara P, Pariat M, Steff AM, Carillo 
S, Piechaczyk M (1999) Are there multiple proteolytic pathways contributing to c-Fos, c-Jun and p53 protein degradation in vivo? Mol Biol Rep 26:45-51.

Schmidt R, Hecker E (1975) Autoxidation of phorbol esters under normal storage conditions. Cancer Res 35:1375-1377.

Schwarz EM, Van Antwerp D, Verma IM (1996) Constitutive phosphorylation of IkappaBalpha by casein kinase II occurs preferentially at serine 293: requirement for degradation of free IkappaBalpha. Mol Cell Biol 16:3554-3559.

Sears R, Leone G, DeGregori J, Nevins JR (1999) Ras enhances Myc protein stability. Mol Cell 3:169-179.

Silva-Neto MA, Fialho E, Paes MC, Oliveira PL, Masuda H (2002) Cyclic nucleotide-independent phosphorylation of vitellin by casein kinase II purified from Rhodnius prolixus oocytes. Insect Biochem Mol Biol 32:847-857.

Skinner M, Qu S, Moore C, Wisdom R (1997) Transcriptional activation and transformation by FosB protein require phosphorylation of the carboxyl-terminal activation domain. Mol Cell Biol 17:2372-2380.

Stemmer C, Schwander A, Bauw G, Fojan P, Grasser KD (2002) Protein kinase CK2 differentially phosphorylates maize chromosomal high mobility group B (HMGB) proteins modulating their stability and DNA interactions. J Biol Chem 277:1092-1098.

Stevens I, Derua R, Rondelez E, Waelkens E, Merlevede W, Goris J (1999) Identification of cyk, a cyclin B2 kinase, as a novel calcium/calmodulindependent protein kinase II and its role during Xenopus laevis oocyte maturation. Exp Cell Res 252:303-318.

Suh HW, Choi SS, Lee JK, Lee HK, Han EJ, Lee J (2004) Regulation of c-fos and c-jun gene expression by lipopolysaccharide and cytokines in primary cultured astrocytes: effect of PKA and PKC pathways. Arch Pharm Res 27:396-401.

Szyszka R, Boguszewska A, Grankowski N, Ballesta JP (1995) Differential phosphorylation of ribosomal acidic proteins from yeast cell by two endogenous protein kinases: casein kinase- 2 and 605 kinase. Acta Biochim Pol 42:357-362.

Tamaoki T, Takahashi I, Kobayashi E, Nakano H, Akinaga S, Suzuki K (1990) Calphostin (UCN1028) and calphostin related compounds, a new class of specific and potent inhibitors of protein kinase C. Adv Second Messenger Phosphoprotein Res 24:497-501.

Torres J, Pulido R (2001) The tumor suppressor PTEN is phosphorylated by the protein kinase $\mathrm{CK} 2$ at its $\mathrm{C}$ terminus. Implications for PTEN stability to proteasome- mediated degradation. J Biol Chem 276:993-998.

Tsubuki S, Saito Y, Tomioka M, Ito H, Kawashima S (1996) Differential inhibition of calpain and proteasome activities by peptidyl aldehydes of di-leucine and tri-leucine. J Biochem (Tokyo) 119:572-576.

Tsurumi C, Ishida N, Tamura T, Kakizuka A, Nishida E, Okumura E, Kishimoto T, Inagaki M, Okazaki K, Sagata N (1995) Degradation of c-Fos by the $26 \mathrm{~S}$ proteasome is accelerated by c-Jun and multiple protein kinases. Mol Cell Biol 15:5682-5687.

Unger GM, Davis AT, Slaton JW, Ahmed K (2004) Protein kinase CK2 as regulator of cell survival: implications for cancer therapy. Curr Cancer Drug Targets 4:77-84.

Vial E, Marshall CJ (2003) Elevated ERK-MAP kinase activity protects the FOS family member FRA-1 against proteasomal degradation in colon carcinoma cells. J Cell Sci 116:4957-4963.

Werme M, Messer C, Olson L, Gilden L, Thoren P, Nestler EJ, Brene S (2002) $\Delta$ FosB regulates wheel running. J Neurosci 22:8133-8138.

Whitmarsh AJ, Davis RJ (2000) Regulation of transcription factor function by phosphorylation. Cell Mol Life Sci 57:1172-1183.

Winter B, Kautzner I, Issinger OG, Arnold HH (1997) Two putative protein kinase CK2 phosphorylation sites are important for Myf-5 activity. Biol Chem 378:1445-1456.

Wisniewski JR, Szewczuk Z, Petry I, Schwanbeck R, Renner U (1999) Constitutive phosphorylation of the acidic tails of the high mobility group 1 proteins by casein kinase II alters their conformation, stability, and DNA binding specificity. J Biol Chem 274:20116-20122.

Yamaguchi Y, Wada T, Suzuki F, Takagi T, Hasegawa J, Handa H (1998) Casein kinase II interacts with the bZIP domains of several transcription factors. Nucleic Acids Res 26:3854-3861.

Yanagawa T, Yuki K, Yoshida H, Bannai S, Ishii T (1997) Phosphorylation of A170 stress protein by casein kinase II-like activity in macrophages. Biochem Biophys Res Commun 241:157-163.

Yankulov K, Yamashita K, Roy R, Egly JM, Bentley DL (1995) The transcriptional elongation inhibitor 5,6-dichloro-1-beta-D-ribofuranosylbenzimidazole inhibits transcription factor IIH-associated protein kinase. J Biol Chem 270:23922-23925.

Yen J, Wisdom RM, Tratner I, Verma IM (1991) An alternative spliced form of FosB is a negative regulator of transcriptional activation and transformation by Fos proteins. Proc Natl Acad Sci USA 88:5077-5081.

Yin X, Jedrzejewski PT, Jiang JX (2000) Casein kinase II phosphorylates lens connexin 45.6 and is involved in its degradation. J Biol Chem 275:6850-6856.

Yoza BK, Brooks JW, Mizel SB (1992) Induction of AP-1 transcription factor components during T-cell activation by interleukin 1 and phorbol esters. Cell Growth Differ 3:677-684.

Yu S, Wang H, Davis A, Ahmed K (2001) Consequences of CK2 signaling to the nuclear matrix. Mol Cell Biochem 227:67-71.

Yu S, Davis AT, Guo C, Green JE, Ahmed K (1999) Differential targeting of protein kinase $\mathrm{CK} 2$ to the nuclear matrix upon transient overexpression of its subunits. J Cell Biochem 74:127-134.

Zachariou V, Bolanos CA, Selley DE, Theobald D, Cassidy MP, Kelz MB, Shaw-Lutchmann T, Berton O, Sim-Selley LJ, DiLeone RJ, Kumar A, Nestler EJ (2006) $\Delta$ FosB: an essential role for $\Delta$ FosB in the nucleus accumbens in morphine action. Nat Neurosci 9:205-211. 